\title{
Basic characteristics of atmospheric particles, trace gases and meteorology in a relatively clean Southern African Savannah environment
}

\author{
L. Laakso ${ }^{1}$, H. Laakso ${ }^{1}$, P. P. Aalto ${ }^{1}$, P. Keronen ${ }^{1}$, T. Petäjä ${ }^{1,2}$, T. Nieminen ${ }^{1}$, T. Pohja ${ }^{1}$, E. Siivola ${ }^{1}$, M. Kulmala ${ }^{1}$, \\ N. Kgabi ${ }^{3}$, M. Molefe ${ }^{3}$, D. Mabaso ${ }^{3}$, D. Phalatse ${ }^{4}$, K. Pienaar ${ }^{5}$, and V.-M. Kerminen ${ }^{6}$ \\ ${ }^{1}$ Department of Physical Sciences, University of Helsinki, P. O. BOX 64, 00014 Helsinki, Finland \\ ${ }^{2}$ Earth and Sun Systems Laboratory, Atmospheric Chemistry Division, Nat. Center for Atmospheric Res., Boulder, CO, USA \\ ${ }^{3}$ Department of Physics, North-West University, Private Bag X 2046, Mmabatho, South Africa \\ ${ }^{4}$ Department of Biology, North-West University, Private Bag X 2046, Mmabatho, South Africa \\ ${ }^{5}$ School of Chemistry, North-West University, Private Bag X 6001, Potchefstroom, South Africa \\ ${ }^{6}$ Finnish Meteorological Institute, P.O. Box 503, 00101 Helsinki, Finland
}

Received: 20 December 2007 - Published in Atmos. Chem. Phys. Discuss.: 27 March 2008

Revised: 25 June 2008 - Accepted: 14 July 2008 - Published: 19 August 2008

\begin{abstract}
We have analyzed one year (July 2006-July 2007) of measurement data from a relatively clean background site located in dry savannah in South Africa. The annualmedian trace gas concentrations were equal to $0.7 \mathrm{ppb}$ for $\mathrm{SO}_{2}, 1.4 \mathrm{ppb}$ for $\mathrm{NO}_{\mathrm{x}}, 36 \mathrm{ppb}$ for $\mathrm{O}_{3}$ and $105 \mathrm{ppb}$ for $\mathrm{CO}$. The corresponding $\mathrm{PM}_{1}, \mathrm{PM}_{2.5}$ and $\mathrm{PM}_{10}$ concentrations were $9.0,10.5$ and $18.8 \mu \mathrm{g} \mathrm{m}^{-3}$, and the annual median total particle number concentration in the size range $10-840 \mathrm{~nm}$ was $2340 \mathrm{~cm}^{-3}$. During Easterly winds, influence of industrial sources approximately $150 \mathrm{~km}$ away from the measurement site was clearly visible, especially in $\mathrm{SO}_{2}$ and $\mathrm{NO}_{\mathrm{x}}$ concentrations. Of gases, $\mathrm{NO}_{\mathrm{x}}$ and $\mathrm{CO}$ had a clear annual, and $\mathrm{SO}_{2}, \mathrm{NO}_{\mathrm{x}}$ and $\mathrm{O}_{3}$ clear diurnal cycle.
\end{abstract}

Atmospheric new-particle formation was observed to take place in more than $90 \%$ of the analyzed days. The days with no new particle formation were cloudy or rainy days. The formation rate of $10 \mathrm{~nm}$ particles varied in the range of $0.1-28 \mathrm{~cm}^{-3} \mathrm{~s}^{-1}$ (median $1.9 \mathrm{~cm}^{-3} \mathrm{~s}^{-1}$ ) and nucleation mode particle growth rates were in the range $3-21 \mathrm{~nm} \mathrm{~h}^{-1}$ (median $8.5 \mathrm{~nm} \mathrm{~h}^{-1}$ ). Due to high formation and growth rates, observed new particle formation gives a significant contribute to the number of cloud condensation nuclei budget, having a potential to affect the regional climate forcing patterns.

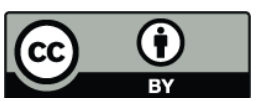

Correspondence to: L. Laakso (lauri.laakso@iki.fi)

\section{Introduction}

Air quality and interactions between land ecosystems and atmosphere in a changing climate are issues that influence most of the developing world. In Africa, for example, changing climate affect vegetation and may thereby cause emigration (Boko et al., 2007). Emigration, on the other hand, increase urban population and air pollution. Although most of the population accumulates into urban areas, air quality is affected also by the surrounding landscape. One spectacular example of this are the intensive dust episodes related to the Kosa desert in Asia, increasing occasionally $\mathrm{PM}_{10}$ concentrations up to values of about $1000 \mu \mathrm{g} \mathrm{m}^{-3}$ (Mori et al., 2002). For that reason, studying the air quality and anthropogenic influences in urban areas requires also knowledge about the natural conditions, and in contrast, urban and industrial plumes may have an adverse effect on vegetation even far a way from the source of emissions. Furthermore, vast areas of even sparse vegetation may contribute significantly to the global atmospheric chemistry (Güenther et al., 1996) and, via the formation of new aerosol particles, to the properties of clouds and global radiation balance (Went, 1960; Kurten et al., 2003; Kerminen et al., 2005).

Africa is one of the least studied continents in the World with respect to air quality (Laakso et al., 2006). Aerosol measurements have been made mainly in equatorial Africa (Andreae et al., 1992; Afeti et al., 1998; Gatari et al., 2005), with the main information coming from the SAFARI-92 and SAFARI 2000 campaigns conducted in the southern parts of Africa (Swap et al, 2003 and references therein). The main

Published by Copernicus Publications on behalf of the European Geosciences Union. 


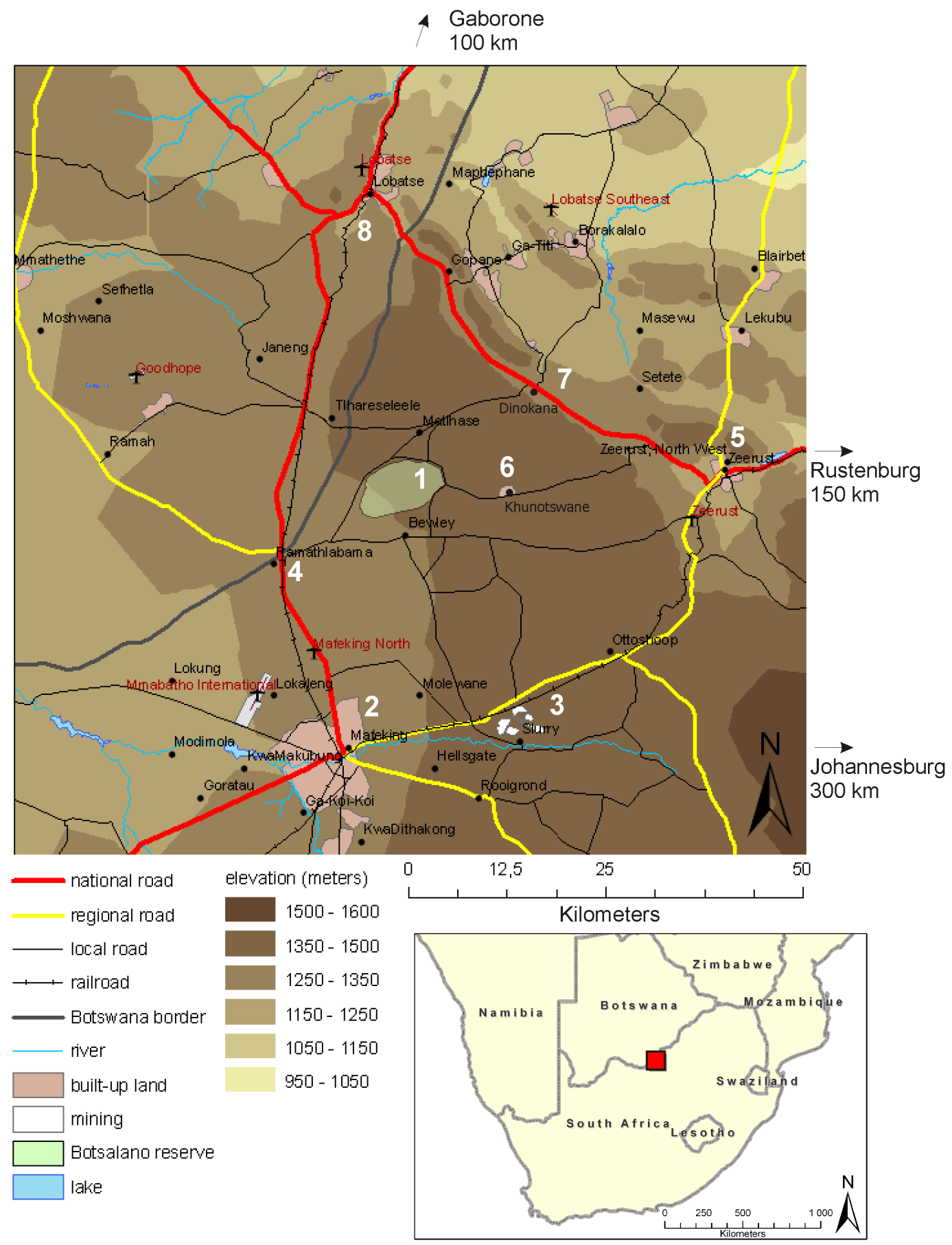

Fig. 1. The measurement site. Location of the detailed map (red square) on a larger scale is indicated on the small map in the lower right hand corner. Detailed map: 1. Botsalano game reserve (measurement site: 25,32'28 S, 25,45'16 E, 1424 m a.s.1.), 2. Mafikeng (population $260000)$, 3. Slurry (cement factory), 4. Ramathlabama (small village and chicken farm), 5. Zeerust (pop. 140 000), 6. Khunotswane (pop. few thousands), 7. Dinokana (pop. $>10000$ ), 8. Lobatse municipal waste burning area. In addition, directions and distances from the measurement site to some regional major pollution sources are shown.

findings from the SAFARI-92 campaign were (1) that the anticyclonic circulation links all the environments in southern Africa, (2) that in addition to biomass burning, there are several other sources of trace gases and aerosol particles in Africa, and (3) that a large fraction of smoke and haze is transported southward from lower latitudes. In the 
SAFARI2000 campaign the focus was in biomass burning plumes due to the exceptional weather conditions. The published results concentrate on the optical and radiative effects of such plumes, including aerosol-cloud interactions (Ross et al., 2003), as well as pollutant emissions from vegetation and fires. In addition to result from the SAFARI campaigns, there is a great deal of publications about VOC emissions from entire savanna, and individual tree species (e.g. Güenther et al., 1996; Otter et al., 2003). Currently, there are also several different studies in the framework of African Monsoon Multidisciplinary Analyses (AMMA) from Western and Central Africa (e.g. Caminade and Terray, 2006) but, to our knowledge, no article based on aerosol observations has been published yet.

Despite some previous observations, combined long-term measurements of trace gas concentrations, aerosol particle mass concentrations and number size distributions (especially in ultrafine size range), air ion number size distributions and meteorological variables are practically nonexistent. Also the exposure of people in Africa to air pollutants in informal settlements, heavily-industrialized areas and mining regions is poorly known (Piketh et al., 2005; Kgabi, 2006).

In order to get a more detailed picture on various aerosol and related trace gas properties in southern Africa, we built a transportable measurement trailer (Petäjä et al., 2007). The trailer is currently located in a game reserve in a savannah environment away from local pollution sources. Later (February 2008 onwards) we will place the trailer in a populated mining region, in an industrial area and in a suburban residential background for one year in each location. Although the meteorological variability from year to year hampers the comparison of measurement results between the different environments, we aim to characterize air quality in these environments and to investigate reasons for observed differences. In this paper, we will describe the measurement site and observational procedures and present a general overview of the measurement results from the period 23 July 2006 to 23 July 2007 in a background savannah environment.

\section{The measurement site and characteristics}

\subsection{The location}

The measurement site considered here is the Botsalano game reserve in North-West Province, South Africa (Fig. 1). The reserve is located in a clean background site about $50 \mathrm{~km}$ north of the nearest city, Mafikeng, with approximately 260000 inhabitants. One of the largest regional pollution sources in North-West Province, Rustenburg mining region, is located approximately $150 \mathrm{~km}$ east of Botsalano (Piketh et al., 2005). Rustenburg is one of the main platinum group metal mining and metallurgical extraction regions in South Africa. Such activities create significant sulphate emissions

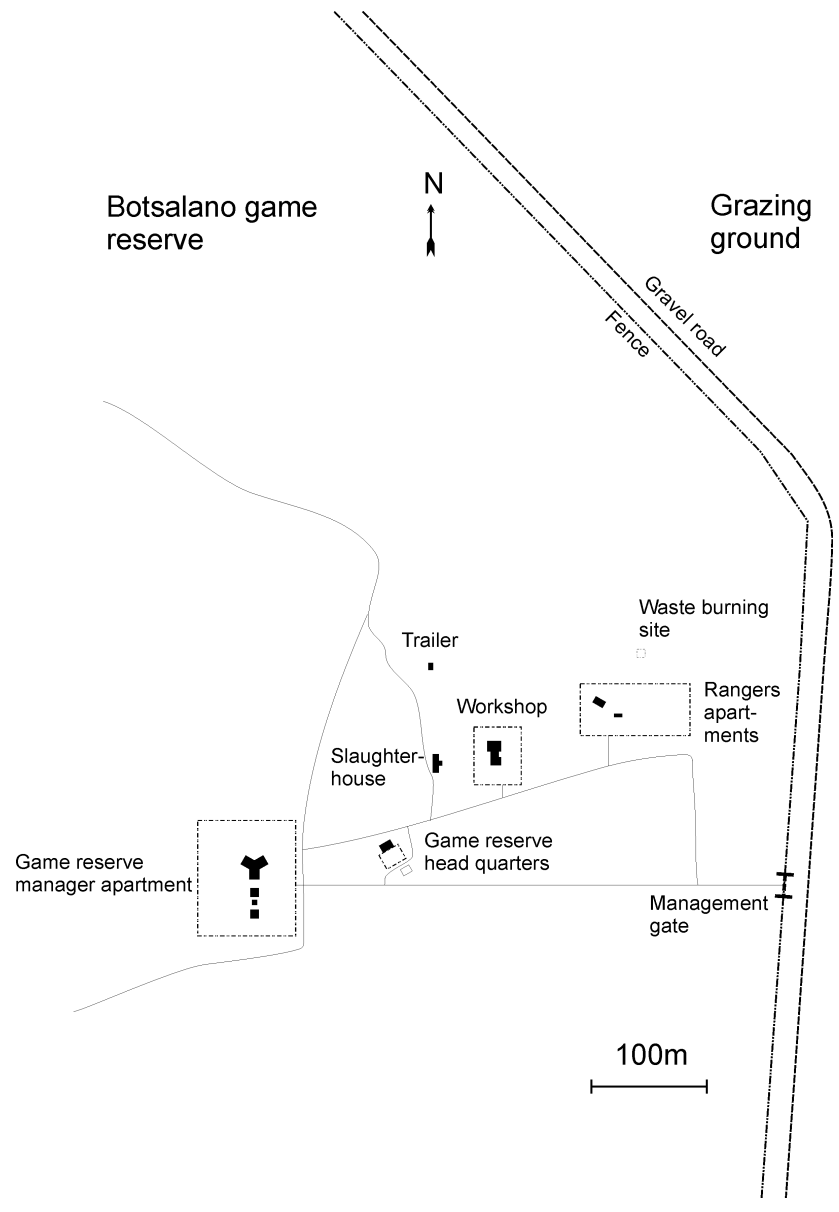

Fig. 2. Measurement site. All roads on the map are gravel roads.

because platinum-group metals are often connected with sulphides. The capital of Botswana, Gaborone, is approximately $100 \mathrm{~km}$ north of Botsalano. Other potential nearby sources affecting the site are shown in Fig. 1.

The neighborhood of the measurement trailer is shown in Fig. 2. All the buildings in the park are heated with electricity. The apartments of rangers and that of managers accommodate eight and one person, respectively. The workshop of the game reserve is used mainly during the mornings between 06:00 and 08:00 local time, whereas the slaughter house is used only few times per year during the hunting season. The waste burning site is used approximately twice a week for a short period, mainly during afternoon hours. Game, mainly antelopes, giraffes, rhinoceros and other herbivores, go freely throughout the reserve. On the savannah grazing ground outside the game reserve, there are sporadically cows and other livestock.

The traffic on the gravel road outside the fence is sparse, totaling a few tens of cars per day. The traffic rate between the management gate, workshop and head quarters is less than 20 cars per day. The road next to the trailer is used a few times per day in maximum. 


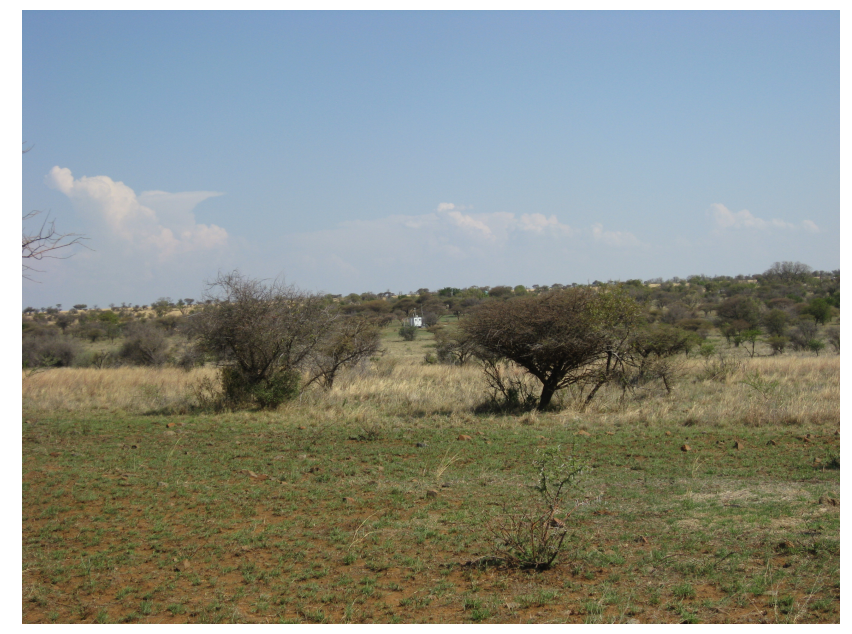

Fig. 3. Surroundings of the trailer (trailer itself is located in the middle of the picture). Picture is taken approximately $300 \mathrm{~m}$ NorthEast of the trailer on 16 October 2007, during the local spring.

\subsection{Synoptic scale meteorology in Botsalano}

The Botsalano game reserve is dry bushveld. The annual precipitation amount, of which approximately $60 \%$ comes during the summer, is $540 \mathrm{~mm}_{\text {year }}{ }^{-1}$. Typical winter temperatures vary between 4 and $20^{\circ} \mathrm{C}$, the summer temperatures being between 17 and $31^{\circ} \mathrm{C}$ (South African weather service, 2007).

The seasons in the region are clearly defined and each of them lasts for a period of approximately three months. The autumn, characterized by relatively high temperatures and relative humidity, lasts from February until April. The winter (May-July) has low temperatures, relative humidities and wind speeds. The spring (August-October) is characterized mainly by low relative humidities, whereas during the summer (November-January) high relative humidities and temperatures together with frequent precipitation are typically encountered.

The large-scale meteorology in the region is characterized by a high degree of stability and anticyclonic circulation (Tyson et al., 1996). Due to a limited vertical mixing, the atmosphere is layered, containing clean and polluted horizontal cells (Hobbs, 2003). The limited vertical mixing, together with high stack heights and anticyclonic circulation, results frequently to a situation in which air masses are contaminated at least to a certain degree, either by industrial sources or by biomass burning. In some cases, air can re-circulate over the sub-continent up to 20 days (Tyson et al., 1996).

\subsection{Vegetation}

The vegetation of the reserve is fairly homogeneous (Fig. 3), consisting of the species of Acacia, Rhus, Ziziphus, Vitex and Grewia as the dominant trees or shrubs typical of a
Table 1. Measurements and devices.

\begin{tabular}{|c|c|c|}
\hline Quantity & $\begin{array}{l}\text { Time } \\
\text { resolution }\end{array}$ & Instrument \\
\hline $\begin{array}{l}\text { Aerosol number size } \\
\text { distribution } 10-840 \mathrm{~nm}\end{array}$ & $7.5 \mathrm{~min}$ & $\begin{array}{l}\text { DMA and } \\
\text { CPC TSI3010 (DMPS) }\end{array}$ \\
\hline $\begin{array}{l}\text { Aerosol mass } \\
\left(\mathrm{PM}_{10}, \mathrm{PM}_{2.5}, \mathrm{PM}_{1}\right)\end{array}$ & $3 \mathrm{~h}$ & $\begin{array}{l}\text { Rupprecht and } \\
\text { Patashnick Co. Inc., } \\
\text { series 1400a TEOM } \\
\text { with special inlet setup }\end{array}$ \\
\hline $\begin{array}{l}\text { Ion number size } \\
\text { distribution } 0.4-40 \mathrm{~nm}\end{array}$ & $5 \mathrm{~min}$ & Air Ion Spectrometer (AIS) \\
\hline $\mathrm{SO}_{2}$ concentration & $1 \mathrm{~min}$ & Thermo-Electron 43S \\
\hline $\mathrm{NO}_{\mathrm{x}}$ concentration & $1 \min$ & Teledyne 200AU \\
\hline $\mathrm{CO}$ concentration & $1 \min$ & Horiba APMA-360 \\
\hline $\mathrm{O}_{3}$ concentration & $1 \mathrm{~min}$ & Environnement s.a $41 \mathrm{M}$ \\
\hline PAR radiation & $1 \mathrm{~min}$ & LiCor LI-190SB \\
\hline Precipitation & $1 \mathrm{~min}$ & Thies 5.4103.20.041 \\
\hline $\begin{array}{l}\text { Wind direction } \\
\& \text { speed }\end{array}$ & $1 \mathrm{~min}$ & $\begin{array}{l}\text { Vector A101ML, } \\
\text { Vector W200P }\end{array}$ \\
\hline $\begin{array}{l}\text { Temperature } \\
\& \text { Relative humidity }\end{array}$ & $1 \mathrm{~min}$ & Rotronic MP 101A \\
\hline
\end{tabular}

savanna biome. Other tree or shrubby species include $E u$ clea undulata, Ozoroa paniculosa, Ximenia caffra and Tarchonanthus comphoroides.

The typical grass species found in this mixed bushveld vegetation include for example Themeda triandra, Cymbopogon plurinoides, Aristida spp., Eragrostis spp., Heteropogon contortus, Schmidtia pappophoroides, Echinochloa sp., Cynodon dactylon, Melinis repens, Elionurus argenteus and Panicum spp.

The herbaceous layer include Hypoxis hemerocallidea, Alternanthera pungens, Nidorella resedifolia, Lippia scaberrina, Commelina livingstonii, Jatropha zeyheri, Hermbstaedtia adorata, Aerva leucura, as well as species of Ophrestia, Cucumis, Solanum and Hibiscus.

Based on the earlier studies, savanna trees like Acacia emits significant amount of isoprene and monoterpenes (e.g. Güenther et al., 1996). Biogenic emissions from other types of vegetation in savannah, such as grass and herbs, are not well known.

\section{Measurements and methods}

Air quality monitoring instruments were mounted into an airconditioned Eurowagon $4500 \mathrm{U}$ trailer (length $4.5 \mathrm{~m}$, width $2.1 \mathrm{~m}$, height $2.3 \mathrm{~m}$, weight $2500 \mathrm{~kg}$ ). The aim of the trailer is to be a self-sufficient and transportable monitoring station. Only prerequisites are three-phase power and periodical maintenance of the instruments. Data is downloaded automatically every day to a server via GRPS-modem. This enables intermittent supervision of the performance of the trailer instruments remotely. 

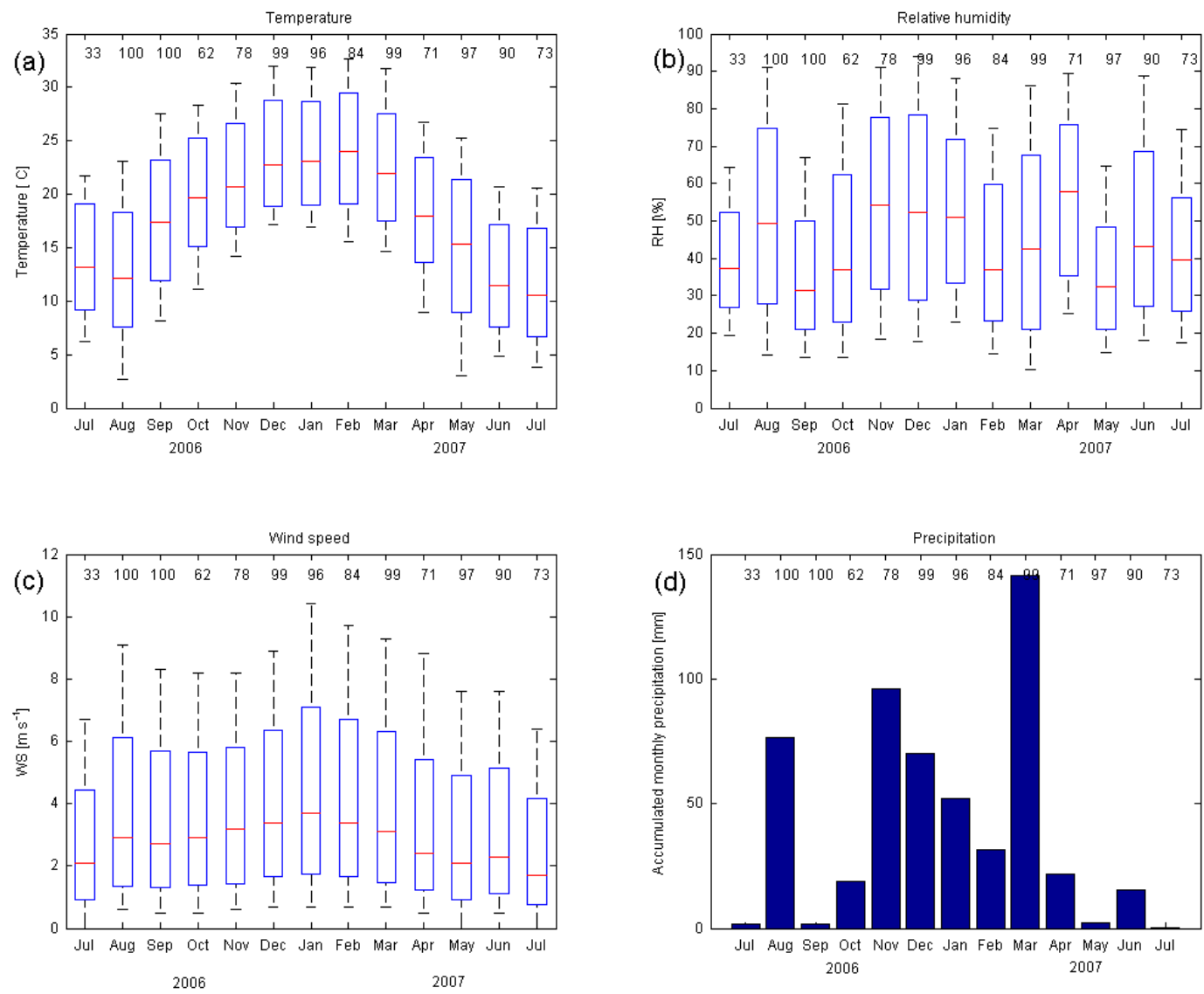

Fig. 4. Monthly variation of (a) temperature (b) relative humidity (c) wind speed (d) monthly accumulated precipitation. Red line in the middle $(\mathrm{a}-\mathrm{c})$ is $50 \%$ percentile, boxes represent 25 and $75 \%$ percentiles and bars 5 and $95 \%$ percentiles. Numbers at the top of each month show the coverage of good quality data for each month in percent.

The instrumentation, technical solutions and calibrations are discussed in detail by Petäjä et al. (2007), so here we summarize them only briefly and present only prime information in Table 1.

Sub-micron aerosol number size distribution was measured with a Differential Mobility Particle Sizer (DMPS, Aalto et al. 2001) in the size range from 10 to $840 \mathrm{~nm}$. The sample was drawn through a Digitel PM2.5 inlet. Prior sizing the particles were dried with a Nafion-drier (Perma Pure LLC, USA) and then brought to a known charging state with a Ni-63 beta-active neutralizer. The particles were classified with a Vienna-type (length $0.28 \mathrm{~m}$ ) Differential Mobility Analyzer (Winklmayr et al., 1991) and counted with a TSI Condensation Particle Counter (CPC) model 3010. Time resolution of the system is $7.5 \mathrm{~min}$.

Concentration of air ions and charged aerosol particles were measured with a Air Ion Spectrometer (AIS, Airel Ltd, Estonia, Mirme et al., 2007). The instrument is a multi-channel, parallel-principle device, measuring simultaneously ion concentrations in 27 mobility fractions of both positive and negative ions. It has two identical cylindrical

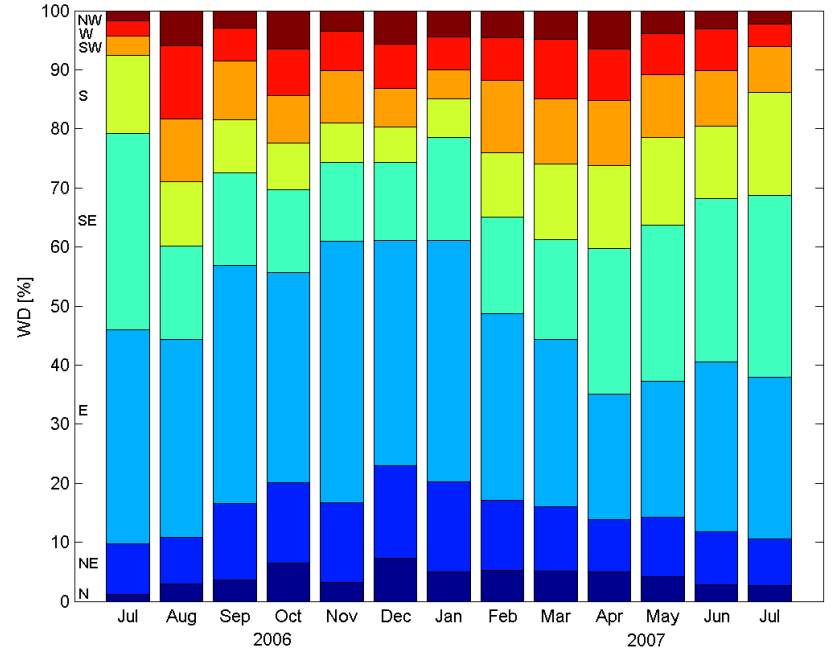

Fig. 5. Frequency distribution of wind direction based on 1-min data. 

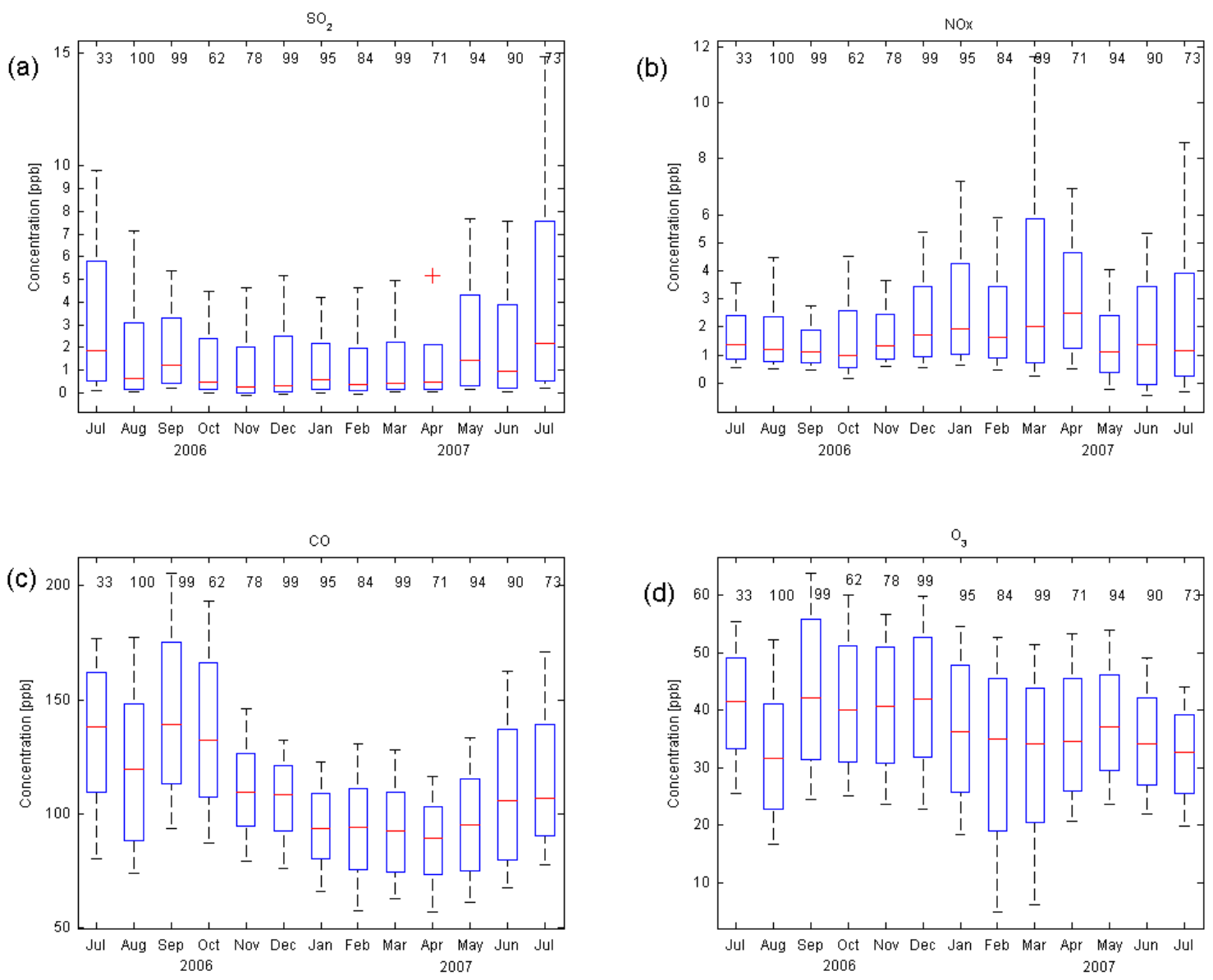

Fig. 6. Annual variation of gaseous pollutants (a) $\mathrm{SO}_{2} ;$ (b) $\mathrm{NO}_{\mathrm{x}}$; (c) $\mathrm{CO}$; (d) $\mathrm{O}_{3}$. Red line in the middle is $50 \%$ percentile, boxes represent 25 and $75 \%$ percentiles and bars 5 and $95 \%$ percentiles. Numbers at the top of each month show the coverage of good quality data for each month in percent.

aspiration-type DMAs, one for each polarity. A radial electrical field separates naturally charged particles (cluster ions and aerosol particles) which are then deposited on different electrodes on the outer core of the DMA depending on their electrical mobility. There are 21 insulated collector electrodes on each of the DMAs. The current carried by the collected ions are amplified and measured. The concentrations of ions with mobilities between 0.0013 to $3.2 \mathrm{~cm}^{2} \mathrm{~V}^{-1} \mathrm{~s}^{-1}$ are monitored. The corresponding diameter range of singlycharged particles is approximately from 0.4 to $40 \mathrm{~nm}$ using modified Millikan formula (Tammet, 1995, 1998). Time resolution is $5 \mathrm{~min}$.

Suspended aerosol mass concentrations were monitored with a Tapered Element Oscillating Microbalance (TEOM) model 1400a (Rupprecht and Patashnick R\&P, Co. Inc.). The sample was drawn to the system via a Thermo Andersen $\mathrm{PM}_{10}$ inlet through a custom made inlet switcher. This switcher alternates between three operation modes enabling consecutive measurements of mass concentrations of $\mathrm{PM}_{10}$, $\mathrm{PM}_{2.5}$ and $\mathrm{PM}_{1}$. In practice a linear motor changed between a straight tube (for $\mathrm{PM}_{10}$ ), a $\mathrm{PM}_{2.5}$ cyclone or a $\mathrm{PM}_{1}$ cyclone in the sampling line. This configuration enabled us to monitor all relevant mass fractions with a single TEOMinstrument with a three hour time resolution. Values for each mass corresponds 20 last min (or 4 last measurement points) for each inlet position, since instrument stabilization takes approximately $40 \mathrm{~min}$ after each inlet mode change.

Gaseous pollutants $\left(\mathrm{SO}_{2}, \mathrm{NO}_{\mathrm{x}}, \mathrm{CO}\right.$ and $\left.\mathrm{O}_{3}\right)$ were monitored in one minute time resolutions with a set of gas analyzers sharing a PTFE-sampling line. Sulfur dioxide was measured with Thermo-Electron $43 \mathrm{~S}, \mathrm{NO}_{\mathrm{x}}$ with a Teledyne 200AU, CO using a Horiba APMA-360 and ozone with an Environnement s.a. $41 \mathrm{~A}$ gas analyzer. The gas data was corrected based on on-site calibrations done in April 2006, May 2007 and October 2007. The calibration coefficients for different gases are given in Appendix A. As clearly visible, $\mathrm{NO}_{x}$ instrument was the most unstable instrument.

Local meteorological parameters (temperature, relative humidity, wind speed and direction, photosynthetically available radiation (PAR) and amount of precipitation were 

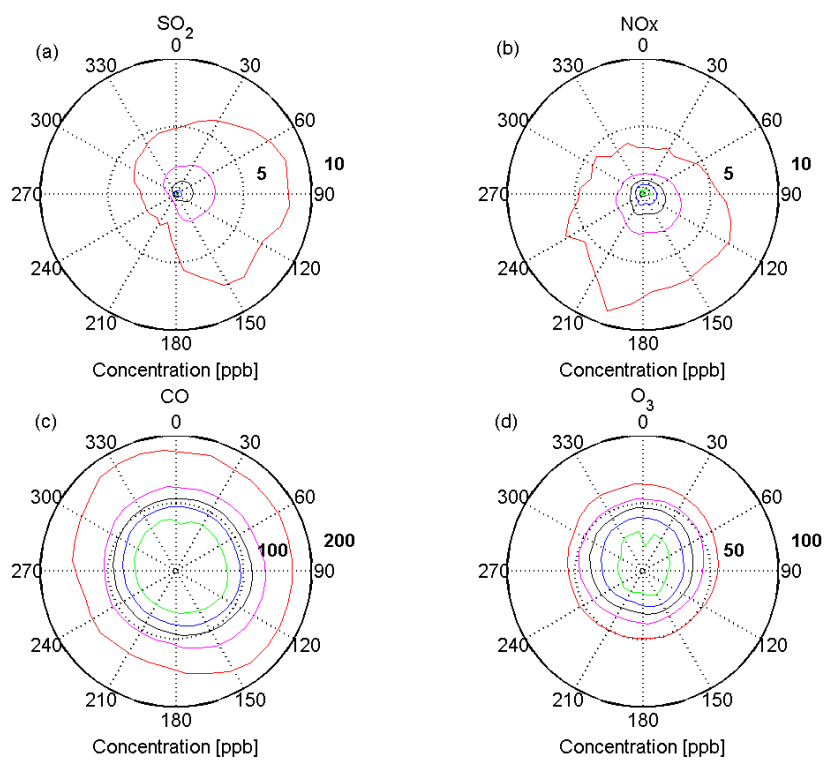

Fig. 7. Gas concentrations as a function of wind direction, (a) $\mathrm{SO}_{2}$; (b) $\mathrm{NO}_{\mathrm{x}}$; (c) $\mathrm{CO}$; (d) $\mathrm{O}_{3}$. Different colors represent percentiles: green: $5 \%$, blue $25 \%$, black $50 \%$, magenta $75 \%$ and red $95 \%$.

logged in one minute time resolution. The meteorological instruments were mounted on a mast located on the roof of the trailer.

All the instruments were checked and maintained weekly, and a full service was made approximately every three months.

Power to trailer in the Botsalano game reserve was taken with a $100 \mathrm{~m}$ long on-ground cable from the workshop (Fig. 2).

The data analyses were carried out using MATLAB scripting language with a trailer_plot_period.m, which automatically filters out questionable data. Such values were recorded quite often after frequent electricity breaks. For the same reason, we used median values instead of means in our subsequent data-analysis. Furthermore, all the gathered data were checked visually to make sure that the questionable data points were excluded.

The number size distributions acquired with the DMPSsystem were the basis of this classification yielding separate datasets for new particle formation events, non-events and undefined days depending on whether new particle formation was observed or not in the DMPS measurement data. The classification was done according to Dal Maso et al. (2005). Also ion measurement data from the AIS were classified in a similar way, and we used the AIS data to support the event classification when the DMPS data not available. We calculated formation rate of the smallest detectable particles of $10 \mathrm{~nm}$ diameter (J10) and the particle growth rate (GR) in size range $10-25 \mathrm{~nm}$ from DMPS size distributions using the method of Dal Maso et al. (2005).
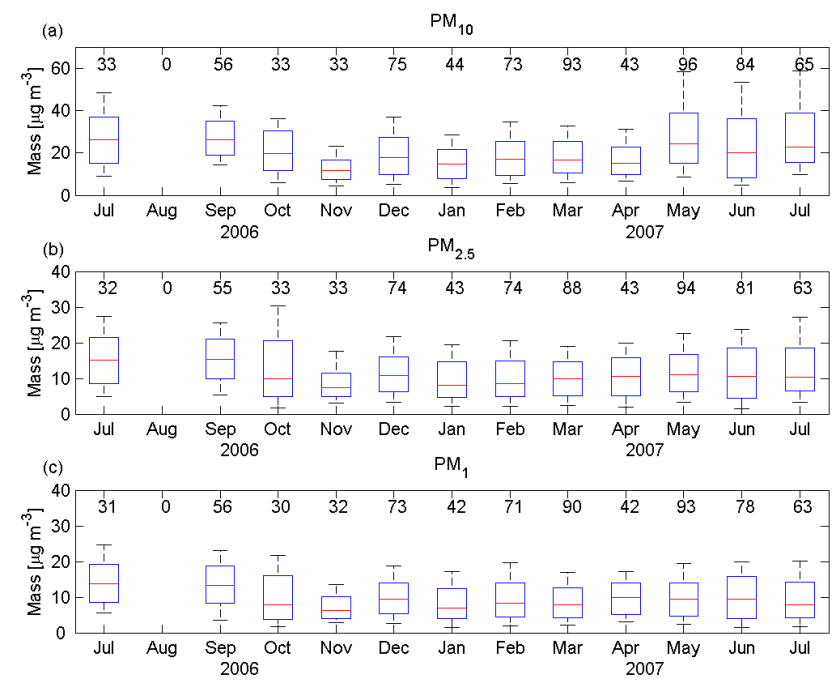

Fig. 8. Particulate mass concentrations for (a) $\mathrm{PM}_{10}$, (b) $\mathrm{PM}_{2.5}$ and (c) $\mathrm{PM}_{1}$. Red line in the middle is $50 \%$ percentile, boxes represent 25 and $75 \%$ percentiles and bars 5 and $95 \%$ percentiles. Numbers at the top of each month show the coverage of good quality data for each month in percent.

In addition to the continuous measurements described in Table 1, we measured intermittenly volatile organic compounds (VOCs) and the chemical composition of aerosol particles in $\mathrm{PM}_{10}, \mathrm{PM}_{2.5}$ and $\mathrm{PM}_{1}$ samples. In August 2007, a new DEBITS-site was started next to the trailer (http://www. igac.noaa.gov/DEBITS.php). DEBITS measurements cover deposition of several biologically important compounds.

\section{Results and discussions}

4.1 Meteorological conditions during the measurement
campaign

The monthly statistics of local meteorological variables are shown in Fig. 4. As can be seen, the monthly-median temperature varied by less than $15^{\circ} \mathrm{C}$ over a course of a year. Freezing temperatures below $0^{\circ} \mathrm{C}$ were encountered only during a couple of nights during the measurement period. In summertime temperatures were relatively frequently in the range 25 $30^{\circ} \mathrm{C}$ and reached occasionally values in excess of $35^{\circ} \mathrm{C}$. Relative humidity was quite low with typical monthly-median values in the range $30-60 \%$. Highest average relative humidities were typically detected during the months with the most frequent precipitation. The winds speed had a clear seasonal trend, being it's highest during the summer months. Most of the precipitation came during the summer.

The seasonal variation of wind direction is shown in Fig. 5. During all seasons, wind was coming most often from the Eastern (NE, E, and SE) sector. As discussed earlier in this 


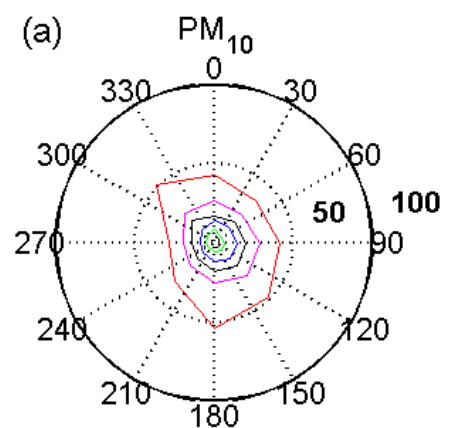

Concentration $\left[\mu \mathrm{g} \mathrm{m}^{-3}\right]$

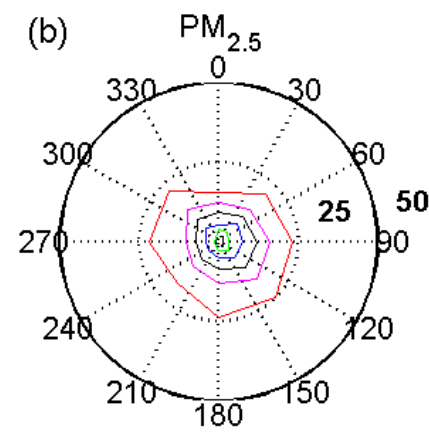

Concentration $\left[\mu \mathrm{g} \mathrm{m}^{-3}\right.$ ]

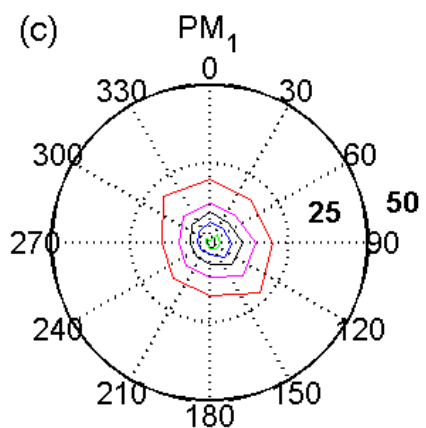

Concentration $\left[\mu \mathrm{g} \mathrm{m}^{-3}\right]$

Fig. 9. Particulate mass as a function of wind direction for (a) $\mathrm{PM}_{10}$, (b) $\mathrm{PM}_{2.5}$ and (c) $\mathrm{PM}_{1}$. Wind directions are the mean wind direction corresponding each mass measurement period. Different colors represent percentiles: green: $5 \%$, blue $25 \%$, black $50 \%$, magenta $75 \%$ and red $95 \%$.

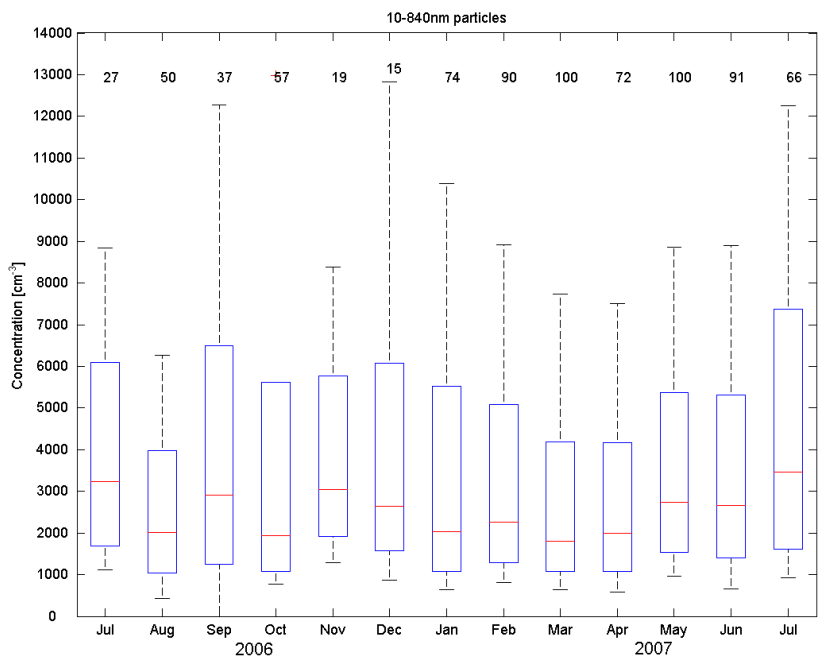

Fig. 10. Annual variability of particle number concentration. Red line in the middle is $50 \%$ percentile, boxes represent 25 and $75 \%$ percentiles and bars 5 and $95 \%$ percentiles. Numbers at the top of each month show the coverage of good quality data for each month in percent.

paper (see also Fig. 1), this is the sector where we can assume most of the anthropogenic pollution originates from.

\subsection{Concentration levels and seasonal cycle of trace gases and aerosol particles}

The monthly-median $\mathrm{SO}_{2}$ concentrations were typically in the range $0.5-2 \mathrm{pbb}$ with an annual median equal to $0.7 \mathrm{ppb}$ (Fig. 6a). The highest $\mathrm{SO}_{2}$ concentrations exceeded $10 \mathrm{ppb}$. Sinha et al. (2003) measured $\mathrm{SO}_{2}$ using an aircraft in August-September during the SAFARI2000 campaign. Their $\mathrm{SO}_{2}$ concentrations were higher than those obtained by us, possibly because the SAFARI flights were closer to the mining and industrial area of Rustenburg and

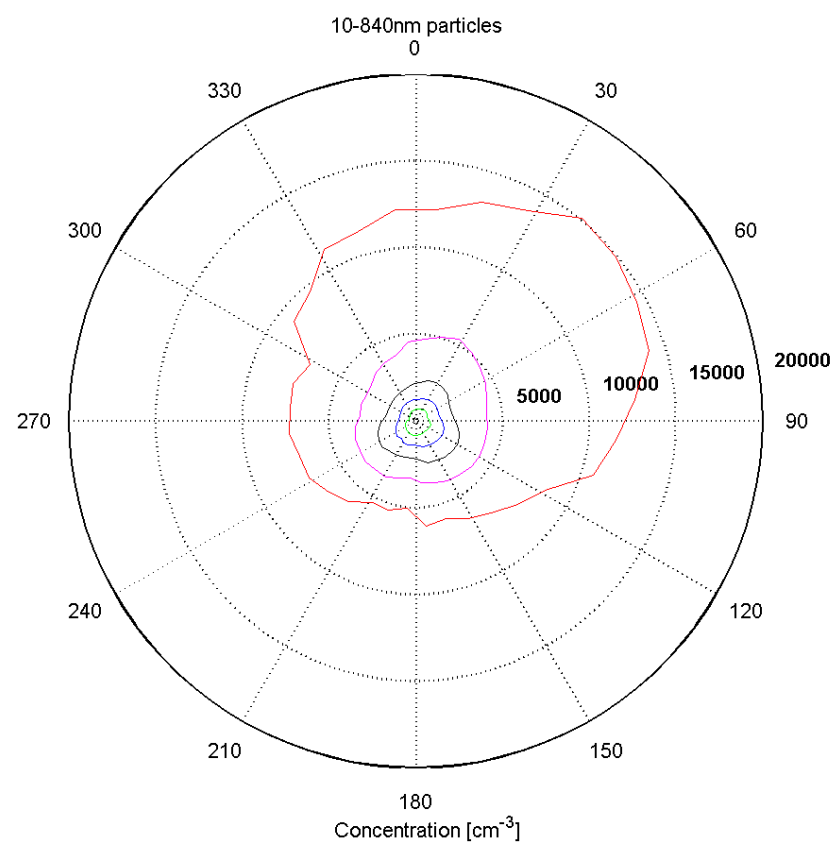

Fig. 11. Total number concentration of particles as a function of wind direction.

Johannesburg. $\mathrm{SO}_{2}$ concentrations over the full annual cycle have been measured in only a few regional locations in Africa, including the sites Elandsfontein (annual median equal to $7 \mathrm{ppb})$ and Cape point $(0.3 \mathrm{ppb})$ in South-Africa (Carmichael et al., 2003). The annual median $\mathrm{SO}_{2}$ concentration measured in equatorial and northern Africa are substantially lower $(<0.1 \mathrm{ppb})$. Overall, most regional background sites in the World show annual median $\mathrm{SO}_{2}$ concentrations less than $1 \mathrm{ppb}$ (Carmichael et al., 2003).

The monthly-median $\mathrm{NO}_{\mathrm{x}}$ concentration varied between 1 and $2.5 \mathrm{ppb}$ with an annual median equal to $1.4 \mathrm{ppb}$ (Fig. 6b). These concentrations are comparable to those observed over 

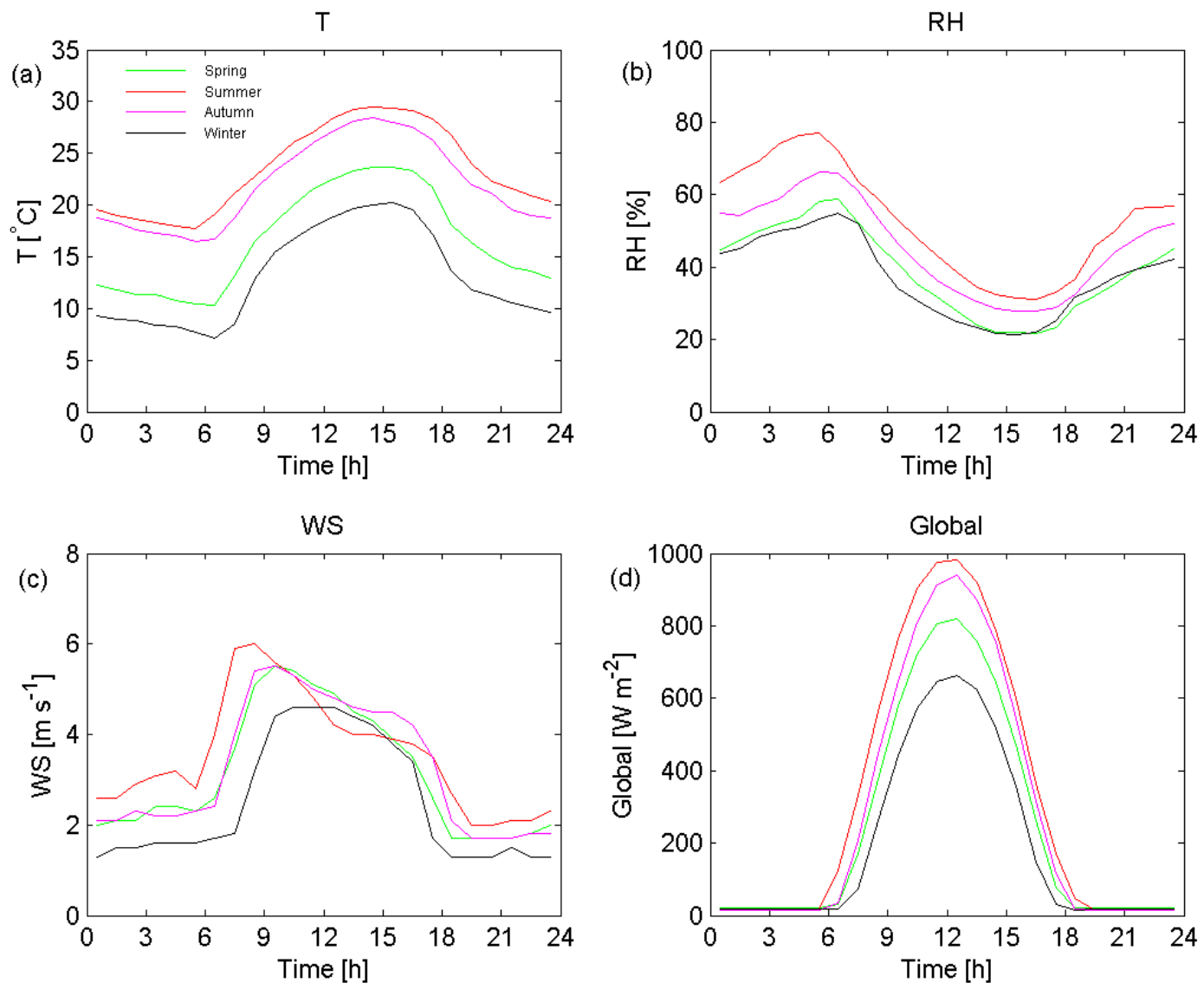

Fig. 12. Diurnal variation of (a) Temperature, (b) Relative humidity, (c) Wind speed and (d) Global radiation during different seasons. Spring: August-October; Summer: November-January; Autumn: February-April; Winter: May-July.

mid-latitude continental areas and substantially larger than those found typically over the southern oceans (Levy et al., 1999).

The monthly-median $\mathrm{CO}$ concentrations varied between about 90 and $140 \mathrm{ppb}$, the annual median value being equal to $104 \mathrm{ppb}$. These values are similar to those measured by Sinha et al. (2003) during the SAFARI2000 campaign but roughly twice those measured annually at Cape Point, South Africa (Duncan et al., 2007). Overall, CO concentrations comparable to our measurements have been reported for continental Europe, North America and Asia (Holloway et al., 2000; Duncan et al., 2007).

The monthly-median ozone concentrations shown varied between 30 and $42 \mathrm{ppb}$ and had an annual median of $36 \mathrm{ppb}$ (Fig. 6d). These values are similar to those reported by Sinha et al. (2003) during the SAFARI2000 campaign but clearly higher than those determined for a few regional sites in Africa (Carmichael et al. 2003). Compared with Europe and North America, the ozone levels in Botsalano are similar to those measured in various background sites but substantially lower than those measured in urban areas (Scheel et al., 1997; Solomon et al., 2000). Average ozone concentrations in polar areas are in the range 20-35 ppb, with slightly higher concentrations in northern than southern hemisphere (Helmig et al. 2007).

Figure 7 shows the measured trace gas concentrations as a function of the local wind direction. We may instantly see that the highest $\mathrm{SO}_{2}$ concentrations were always associated with easterly winds bringing heavily-polluted air from the Rustenburg mining region approximately $150 \mathrm{~km}$ east of Botsalano. During westerly winds $\mathrm{SO}_{2}$ concentrations were very low, typically around $0.5 \mathrm{ppb}$ or less. The $\mathrm{NO}_{\mathrm{x}}$ concentrations were highest when the wind blew from the direction of Mafikeng. The CO concentrations were more homogeneously distributed between the different wind directions, even though a minor increase in the $\mathrm{CO}$ concentrations due in $\mathrm{NE}$ to $\mathrm{E}$ directions could be addressed to the nearby villages of Khunotswane and Dinokana. In contrast to $\mathrm{SO}_{2}$ and $\mathrm{NO}_{\mathrm{x}}$, ozone did not have any significant dependence on the wind direction.

The relatively even distributions of the $\mathrm{CO}$ and $\mathrm{O}_{3}$ concentrations between the different wind sectors is probably attributed to the fact that these pollutants are mostly of secondary origin and their formation is due to a combination 


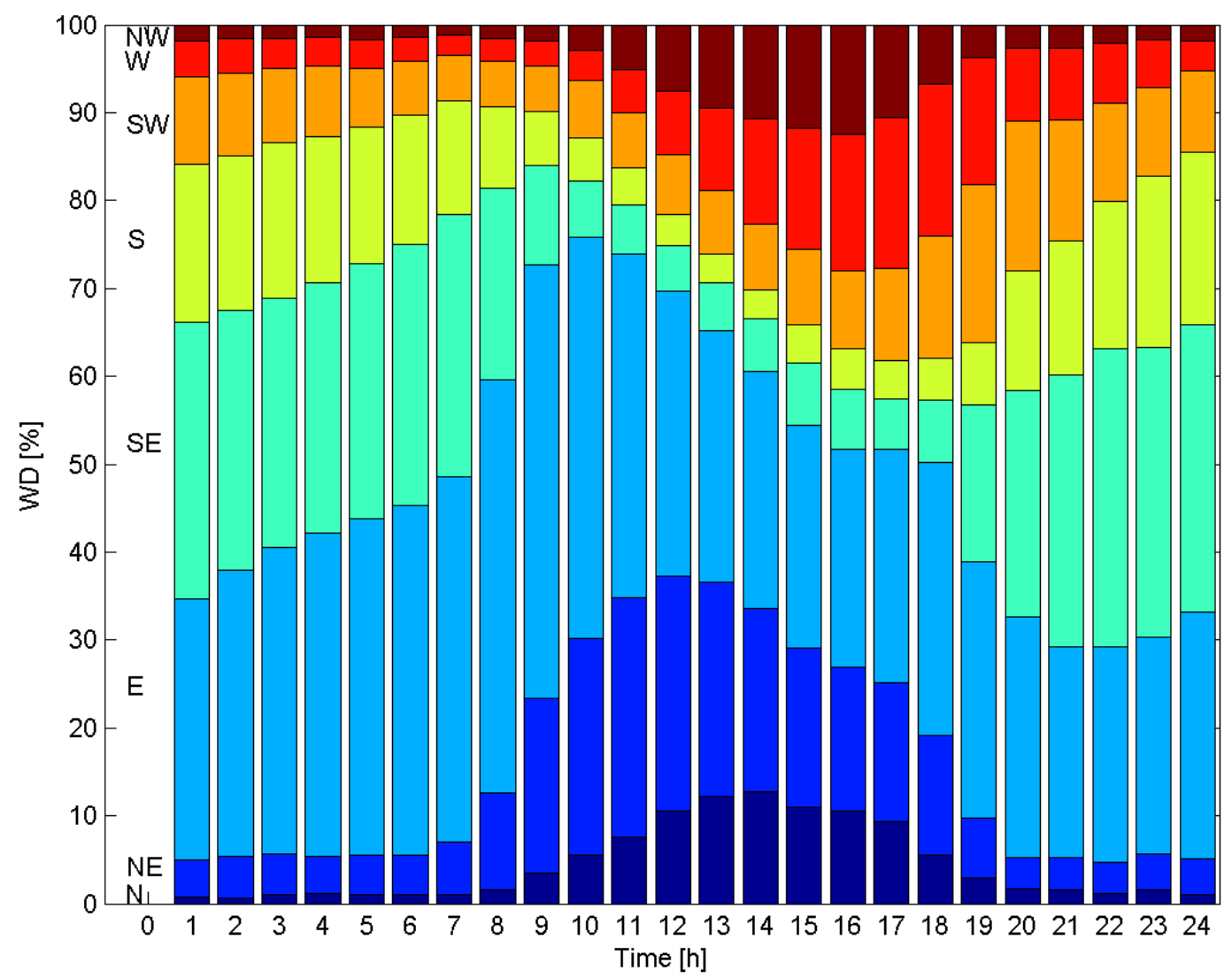

Fig. 13. Diurnal frequency distribution of wind direction in Botsalano game reserve, South Africa for the period 23 July $2006-23$ July 2007.

of several primary pollutants and meteorological conditions. $\mathrm{O}_{3}$, for example, results from $\mathrm{VOC}$ and $\mathrm{NO}_{2}$, whereas $\mathrm{CO}$ originates from the oxidation of biogenic hydrocarbons, soil, termites and vegetation (Finlayson-Pitts and Pitts, 2000; Holloway et al., 2000). The North-East sector was somewhat elevated for $\mathrm{CO}$ probably due to biomass burning sources at lower latitudes, and domestic burning in local villages in that direction.

The concentrations of measured trace gases had different seasonal cycles. The monthly-median $\mathrm{SO}_{2}$ concentrations peaked during the late autumn/early winter (May-July), being 2-4 higher than the corresponding values during the rest of the year (Fig. 6a). This feature cannot be explained by the seasonal variability of the wind direction (Fig. 5) but is more likely the result of less effective mixing and weaker dilution of $\mathrm{SO}_{2}$ originating from the Rustenburg mining area during the cold periods. The seasonal cycle of $\mathrm{NO}_{\mathrm{x}}$ was not very clear, even though elevated monthly-median concentrations were observed during summer and especially autumn (March-April). The CO concentration had a pronounced seasonal cycle, with low values during the summer and autumn and up to 1.5 times higher monthly-median concentrations during the late winter and spring (Fig. 6c). The most probable reason for the elevated $\mathrm{CO}$ concentration during the driest months were regional bush fires and possibly more distant biomass burning sources.

The $\mathrm{O}_{3}$ concentrations were highest in spring. Such a spring maximum is typical for coastal and remote sites in Europe, as well as for Arctic areas and northern Atlantic (Oltmans and Levy, 1992; Scheel et al., 1997; Rodriquez and Guerra, 2004; Helmig et al., 2007). On the contrary, the ozone concentrations tend to peak during summer in many polluted sites and in Antarctica (Scheel et al., 1997; Rodriquez and Guerra, 2004; Helmig et al., 2007). Noteworthy in our data is the rather weak seasonal variation of the ozone concentration. In most surface sites, the annual cycle of monthly-median ozone concentration is more than 15 ppb (e.g. Scheel et al., 1997; Rodriquez and Guerra, 2004; Helmig et al., 2007).

Figure 8 shows the monthly statistics of measured $\mathrm{PM}_{1}$, $\mathrm{PM}_{2.5}$ and $\mathrm{PM}_{10}$ concentrations. Similar to the $\mathrm{CO}$ data, the highest concentrations were observed during the late winter, especially for $\mathrm{PM}_{1}$ and $\mathrm{PM}_{2.5}$. The $\mathrm{PM}_{10}$ concentration increased earlier during the winter (May-July, 2007), being indicative of the presence of coarse dust particles from deserted areas (e.g. Kalahari) during that period of the year. Annual median concentrations of $\mathrm{PM}_{1}, \mathrm{PM}_{2.5}$ and $\mathrm{PM}_{10}$ were equal to $9.0,10.5$ and $18.8 \mu \mathrm{g} \mathrm{m}^{-3}$, respectively. These values are 

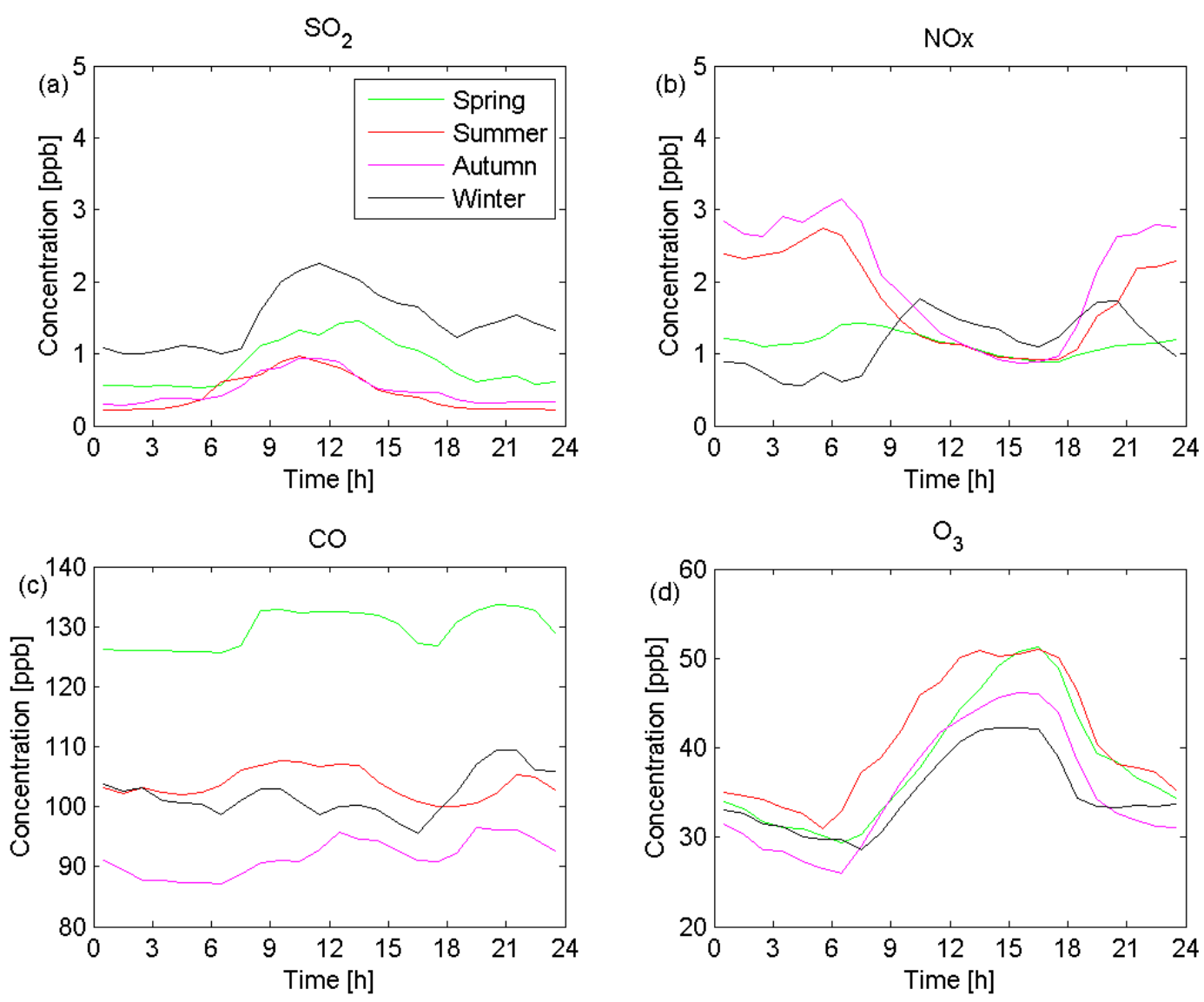

Fig. 14. Diurnal variation of (a) $\mathrm{SO}_{2}$, (b) $\mathrm{NO}_{\mathrm{x}}$, (c) $\mathrm{CO}$ and (d) $\mathrm{O}_{3}$ for each season.

comparable to those observed in rural or continental background locations in Europe and Northern America (Brook et al., 1997; Eldred et al., 1997, Van Dingenen et al., 2004).

Figure 9 shows the relation between the particle mass concentrations and wind direction. We see that the $95 \%$ percentile of $\mathrm{PM}_{10}$ is somewhat elevated in the North-West and South-East sectors, the former being probably due to the dust from Kalahari (approximately $500 \mathrm{~km}$ away) and the latter due to activities in the direction of game park management gate and workshop (Fig. 2). Measured $\mathrm{PM}_{2.5}$ and $\mathrm{PM}_{1}$ concentrations were relatively equally distributed between the different wind sectors.

The total particle number concentration in the size range $10-840 \mathrm{~nm}$ (Fig. 10) had an annual median of $2340 \mathrm{~cm}^{-3}$ with no clear seasonal trend. The monthly-median values were typically between 2000 and $3500 \mathrm{~cm}^{-3}$. The highest particle number concentrations were due to daytime new-particle formation events discussed in more detail in Sect. 4.5. The values shown here compare relatively well to those by Sinha et al. (2003), the differences being probably due to the combined effects different measured size range and new-particle formation. The measurement flights by Sinha et al. (2003) were carried out in the middle of the day at the time when we observed most intensive new-particle formation. The highest particle number concentrations were observed in the same wind sector as the highest $\mathrm{SO}_{2}$ concentrations (Fig. 11). The reason for this is discussed shortly in Sect. 4.5.

\subsection{Diurnal cycles}

In addition to seasonal variations, we also investigated diurnal variation of the measured quantities during the different seasons. Of temperature, relative humidity, wind speed and global radiation (Fig. 12), it is interesting to note the very clear diurnal behavior of the wind speed, with highest values observed typically during the mornings and relatively low values during the nights. The wind direction had also a diurnal pattern (Fig. 13). Winds coming from East-North-East sector were frequent in the morning, turning more toward the West during the afternoon. A detailed trajectory analysis concerning the influences of air mass origin and local topography on measured aerosol and trace gas concentrations will be carried out after we have completed the measurements in Botsalano in January 2008.

The $\mathrm{SO}_{2}$ concentration had a clear diurnal cycle in all the seasons with peak values observed typically before the noon (Fig. 14a). The clear night-time minimum in $\mathrm{SO}_{2}$ 

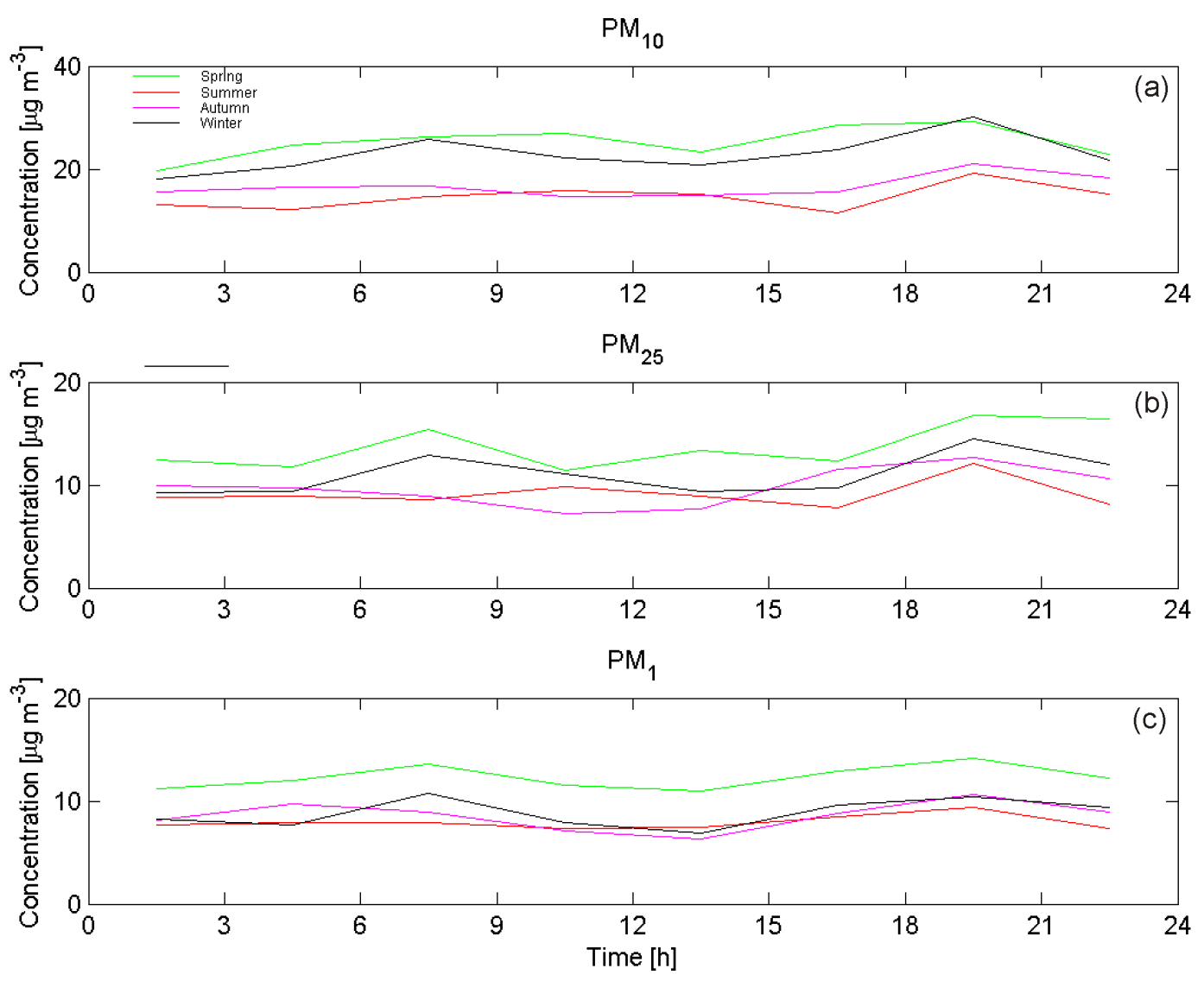

Fig. 15. Diurnal variation of (a) $\mathrm{PM}_{10}$, (b) $\mathrm{PM}_{2.5}$ and (c) $\mathrm{PM}_{1}$ during different seasons.

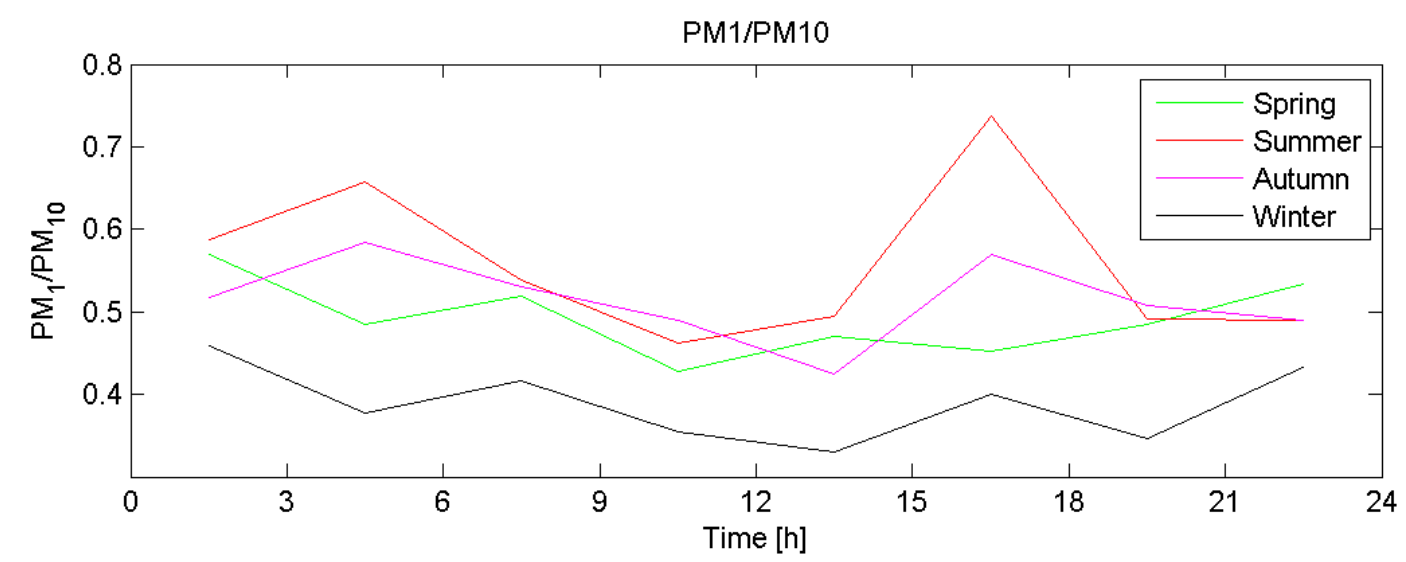

Fig. 16. $\mathrm{PM}_{1} / \mathrm{PM}_{10}$ in Botsalano game reserve as a function of time of the day for different seasons.

concentrations is probably due to the combination of the typical presence of strong night-time inversion, which prevents the downward mixing of $\mathrm{SO}_{2}$ rich air as observed in case of power plant plumes (e.g. Querol et al., 1998), and lack of major local sources for this compound. The concentrations of $\mathrm{NO}_{\mathrm{x}}$ and $\mathrm{O}_{3}$ were strongly anticorrelated over the diurnal cycles as one would expect (Fig. 14b, d) (e.g. Finlayson-Pitts and Finlayson, 2000). The night-time behavior of the $\mathrm{NO}_{\mathrm{x}}$ concentration during winter and spring differed significantly from that during summer and autumn. The reason for the winter anomaly is biological activity in the ground related to the availability of the water during the humid season, which increases NO emissions (Otter et al., 1999). The CO concentrations had a weak late afternoon minimum potentially 


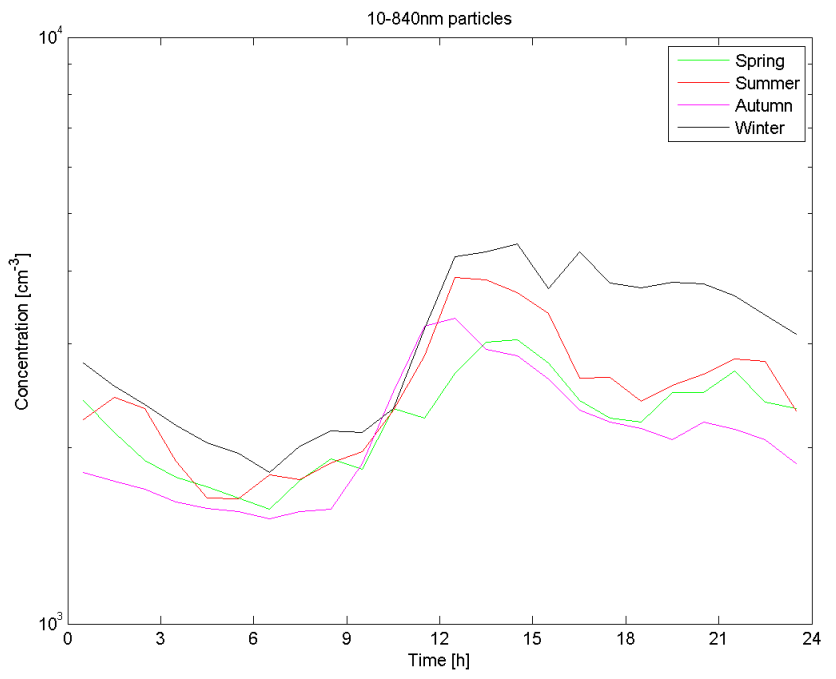

Fig. 17. Diurnal variation of $10-840 \mathrm{~nm}$ particles during different seasons.

due to the rapid reaction of $\mathrm{CO}$ with the $\mathrm{OH}$ radical. The high spring values for $\mathrm{CO}$ are attributed to biomass burning during the dry period as mentioned earlier in Sect. 4.2.

Figures 15 and 16 depict the diurnal cycles of $\mathrm{PM}_{1}, \mathrm{PM}_{2.5}$ and $\mathrm{PM}_{10}$ concentrations and ratio of $\mathrm{PM}_{1}$ to $\mathrm{PM}_{10}$ concentrations during the different seasons. During some periods a bimodal structure with a morning and late afternoon/evening maximum can be distinguished. In urban areas such a structure is attributed usually to the combined effect of traffic emissions and dilution, but this cannot be the case here due to the very low traffic amounts. PM values presented here are comparable to those observed in Northern Zimbabwe, approximately $1000 \mathrm{~km}$ North-East of our measurement site reported by Nyanganyura et al. (2007). The average decrease of the $\mathrm{PM}_{1}$ to $\mathrm{PM}_{10}$ concentration ratios throughout the morning until late afternoon coincides with the period of high wind speeds and might therefore be indicative of the influence of desert dust. In summer and autumn, the high $\mathrm{PM}_{1}$ to $\mathrm{PM}_{10}$ concentration ratios during the late afternoon could be due to secondary aerosol formation associated with biogenic precursor emissions. It appears that multiple sources together with variable mixing conditions, rather than a single source or factor, is needed to explain the diurnal cycle of observed PM concentrations. In general our $\mathrm{PM}_{2.5}$ to $\mathrm{PM}_{10}$ concentration ratios are comparable those observed in sites affected frequently by desert or road dust, such as the semiarid regions of Southern Europe, whereas much higher $\mathrm{PM}_{2.5}$ to $\mathrm{PM}_{10}$ concentration ratios are usually observed in polluted urban areas (e.g. Eldred et al., 1997; Querol et al., 2004; Van Dingenen et al., 2004; Rodrigues et al., 2007).

The total particle number concentration was found to peak very clearly in the afternoon (Fig. 17), which is related to new-particle formation taking place almost every day. During the winter, total particle number concentrations
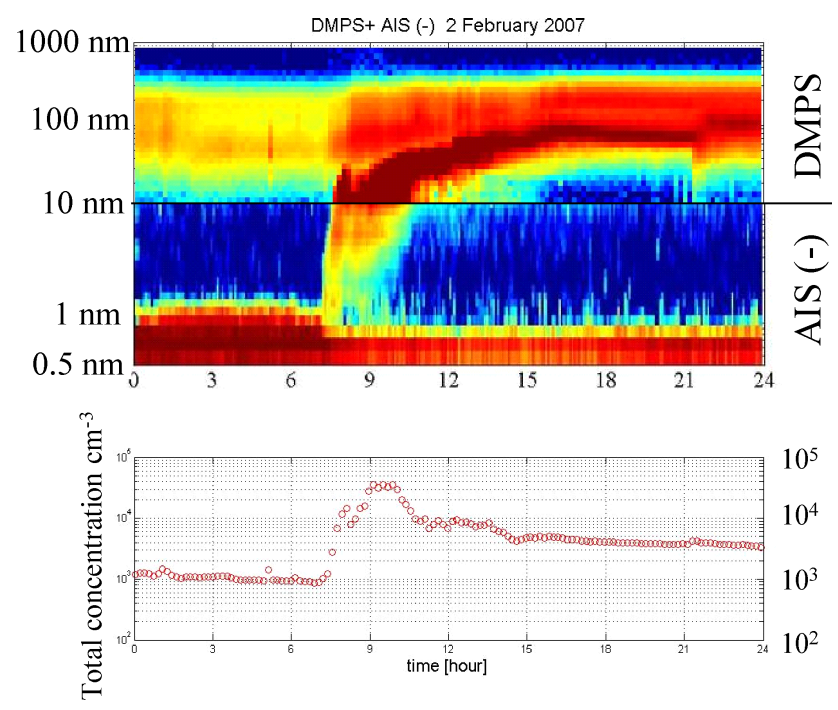

Fig. 18. New particle formation event on 2 February 2007. Figure is merged from negative AIS and DMPS data and it is shown for illustrative purposes only.

decreased much less rapidly toward the night and morning than during other seasons. Potential reasons for this might be the low winter-time wind speeds resulting in less efficient particle dry deposition and dilution, as well as the influence of smoke from the nearby villages and settlements (e.g. Khunotswane and Dinokana).

\subsection{Correlations}

In order to get a more detailed insight into the potential connection between measured quantities, we calculated correlation coefficients between the trace gas and particle concentrations. The correlation coefficients were calculated separately for the morning hours (06:00-12:00), afternoon (12:00-18:00) and nighttime (21:00-03:00). Among the trace gases, the best correlation was seen between $\mathrm{SO}_{2}$ and $\mathrm{NO}_{\mathrm{x}}(\mathrm{R}=0.5-0.7)$ during both morning and afternoon. A weak correlation between $\mathrm{CO}$ and $\mathrm{O}_{3}$ was also seen throughout the day, as well as a weak anti-correlation between $\mathrm{NO}_{\mathrm{x}}$ and $\mathrm{O}_{3}$. These features are consistent with two major anthropogenic source types affecting the site, namely biomass burning and industrial emissions, with traffic having a very small influence. The PM concentrations correlated weakly with both $\mathrm{SO}_{2}$ and $\mathrm{CO}$ throughout the day and with $\mathrm{O}_{3}$ during the afternoon and nighttime. This confirms that measured particulate matter concentrations are affected by at least industrial emissions, biomass burning and secondary aerosol formation, with no apparent dominance by a single source. The accumulation mode $(100-840 \mathrm{~nm})$ particle number concentration correlated with various trace gases in a similar way as did the PM concentration, which is expected. The Aitken mode $(25-100 \mathrm{~nm})$ particle number concentration correlated 


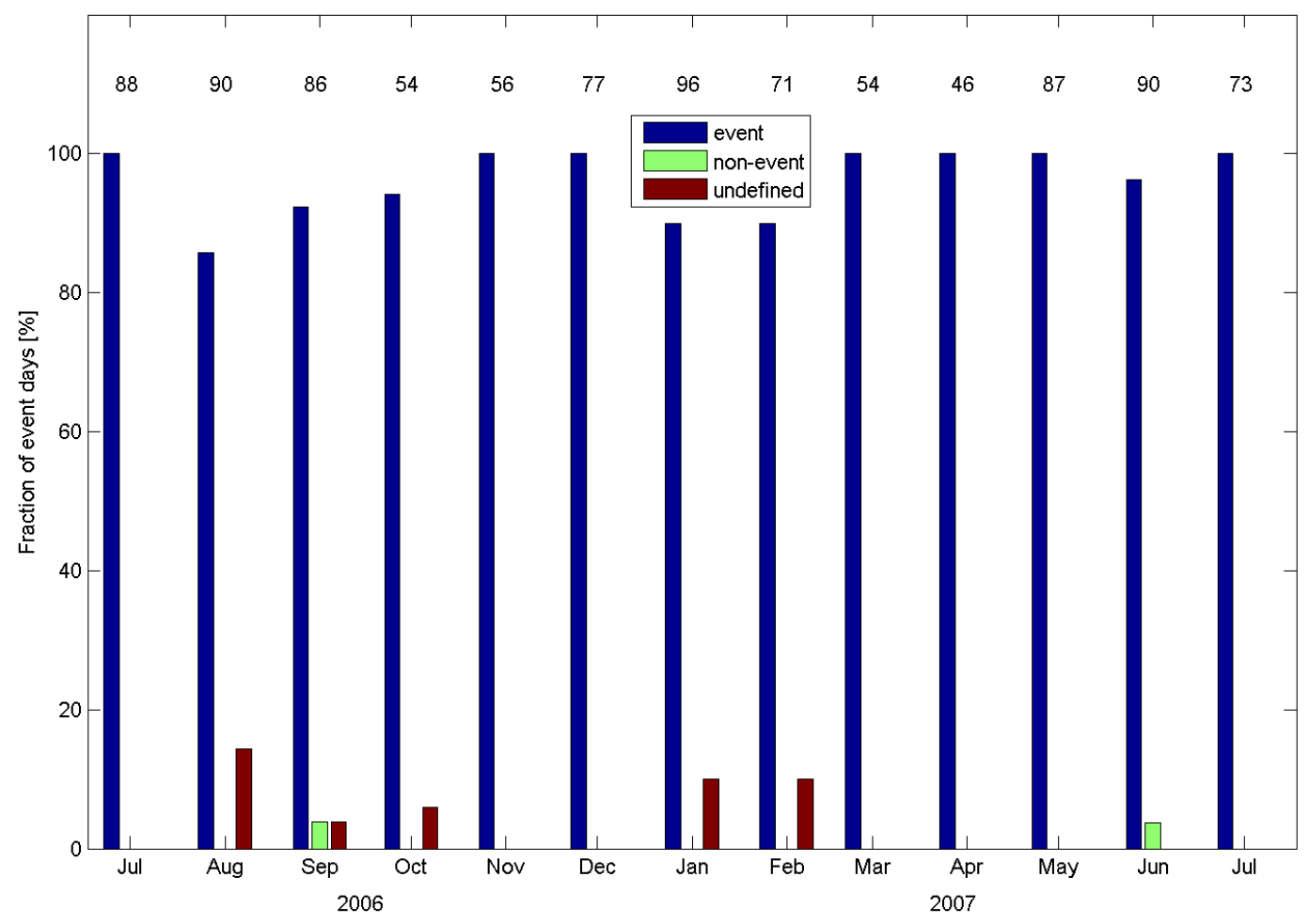

Fig. 19. Fraction of new particle formation days observed with DMPS and/or AIS. Numbers at the top of each month show percentage of data available for each month.

( $\mathrm{R}=0.3-0.5)$ with $\mathrm{SO}_{2}$ only, whereas the nucleation mode (10-25 nm) particle number concentration had practically no correlation with any trace gas, except a weak correlation with $\mathrm{SO}_{2}$ during the morning hours. This could be explained by the dominance of secondary formation pathways for both nucleation and Aitken mode particles, aided somewhat by the presence of high $\mathrm{SO}_{2}$ concentrations, and hindered by high pre-existing particle surface area.

\subsection{New-particle formation episodes}

New particle formation was frequent in Botsalano. Figure 18 shows a typical new-particle formation day observed in Botsalano. During this day, nucleation started soon after sunrise and lasted for approximately three hours. The average formation rate of $10 \mathrm{~nm}$ particles was $6.7 \mathrm{~cm}^{-3} \mathrm{~s}^{-1}$ and the average particle growth rate was $9.7 \mathrm{~nm} \mathrm{~h}^{-1}$. About 30000 new particles $\mathrm{cm}^{-3}$ were formed into the size range $>10 \mathrm{~nm}$ during the day.

Figure 19 shows the frequency of the observed newparticle formation events in each month. The events were analyzed separately from the AIS and DMPS data. We had several periods when only one of the devices worked properly but, due to the overlapping size range of $10-40 \mathrm{~nm}$, the analyzed days are well comparable. The event probability was very high, taking place on more than $90 \%$ of the days. Days without new-particle formation (non-events), as well as undefined days, corresponded mainly to cloudy or rainy days.

Figure 20 shows the formation rate of $10 \mathrm{~nm}$ particles for those days when DMPS data was available (approximately $60 \%$ of the time). The observed formation rates varied between about 0.1 and $28 \mathrm{~cm}^{-3} \mathrm{~s}^{-1}$ with no clear seasonal cycle. The corresponding particle growth rates varied between 3 and $21 \mathrm{~nm} \mathrm{~h}^{-1}$, again with no clear seasonal cycle.

If we compare the observations with measurements carried out in other sites (see Kulmala et al., 2004, and references therein) as well as recent study from Po-valley, Italy (Hameed et al., 2007) we notice that the frequency of the new-particles formation events, as also the particle formation and growth rates, are among the highest observed in continental areas. Other important difference is the any lack of seasonal variability - clearly, we have enough nucleating and condensing vapors as well as solar radiation for nucleation to take place throughout the year.

\section{Summary and conclusions}

In this paper, we have introduced a new atmospheric measurement site in Southern African savannah and presented the main results from a full year of aerosol and trace gas measurements. Based on the conducted measurements, we can state that our site is in general relatively clean but influenced 

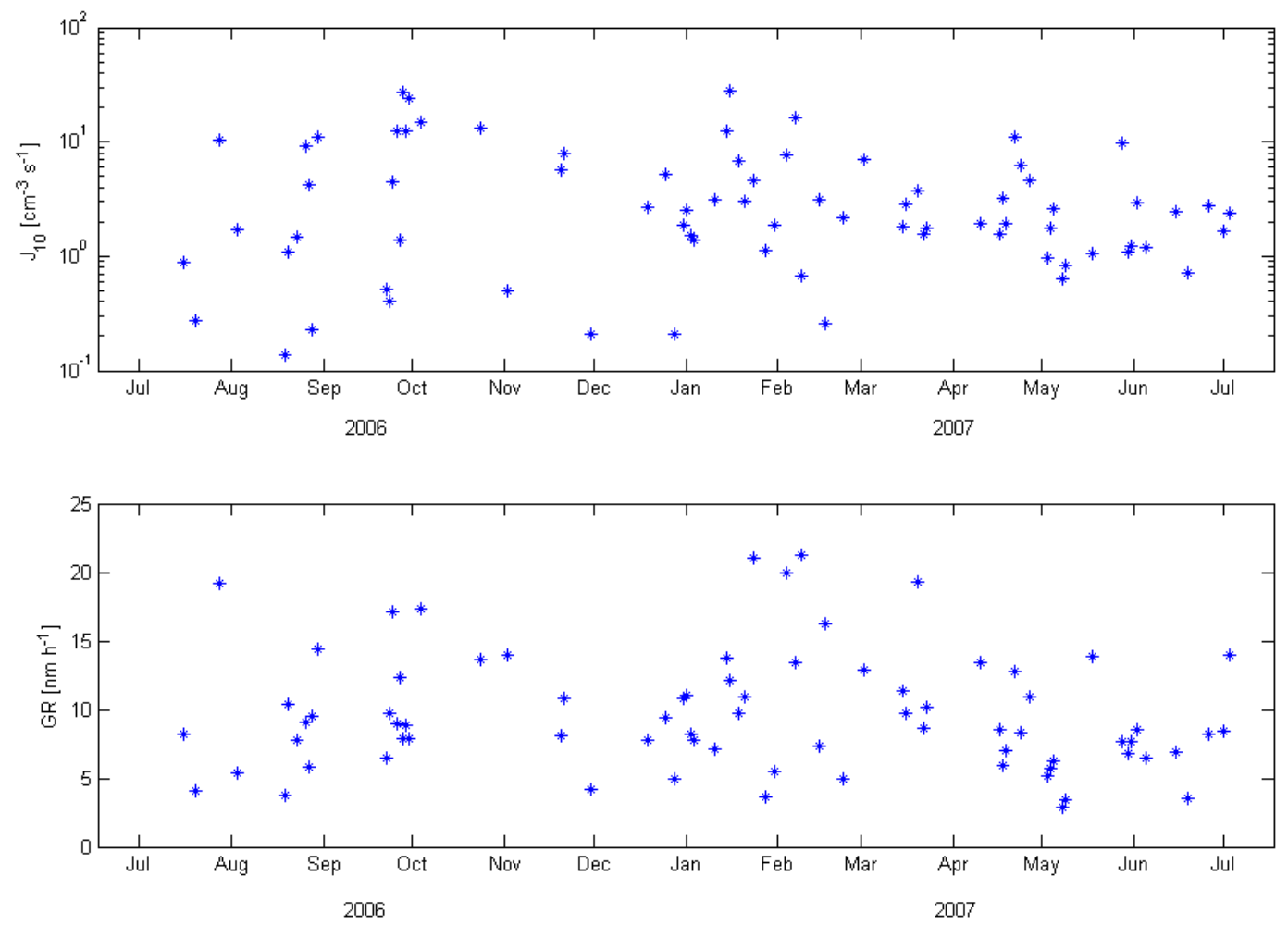

Fig. 20. Upper panel: formation rate of $>10 \mathrm{~nm}$ particles in nucleation burst. Lower panel: nucleation mode particle growth rates. Note that data have gaps during the periods when DMPS has not worked, longest gaps are in September and November 2006.

occasionally by anthropogenic plumes. As a result, the site provides an optimal location between polluted industrial regions to the East and clean, sparsely-populated regions to the West of the measurement site. The location allows us to investigate the influences of sources in different regions with the help of air mass trajectories.

Our observations provided information on trace gas concentration, aerosol particle properties and meteorological variables. When comparing the measurement results with those obtained from earlier studies, we found that the concentrations of trace gases were in the level reported in literature, with seasonal and diurnal variations influenced by both biological activity and local meteorology.

Since there is no prior measurements of aerosol particle number size distributions from the regions, we observed for the first time that new particle formation takes place almost every day in such an environment. Due to the high growth rates, the fresh-formed particles reach easily sizes at which they can act as cloud condensation nuclei and affect thereby the regional radiation balance.

The first analysis of the data set raised also several questions, such as what is the effect of volatile organic compounds on new-particle formation and growth and how different sources influence trace gas and aerosol concentrations. These issues will be discussed in more detail in our future publications.

\section{Appendix A}

\section{Calibration coefficients for gas analyzers}

Gases are corrected assuming "a" and "b" to change linearly between the calibration dates. In $\mathrm{SO}_{2}$, also the pressure effects are taken into account. Values shown in this article are corrected as

$\mathrm{c}_{\text {corrected }}=\mathrm{a}(t) \cdot \mathrm{c}_{\text {meas }}+\mathrm{b}(t)$

\begin{tabular}{lllllll}
\hline & \multicolumn{2}{l}{ 10 April 2006 } & \multicolumn{2}{l}{ 15 May 2007 } & \multicolumn{2}{l}{ 15 October 2007 } \\
\hline & $\mathrm{a}$ & $\mathrm{b}$ & $\mathrm{a}$ & $\mathrm{b}$ & $\mathrm{a}$ & $\mathrm{b}$ \\
$\mathrm{SO}_{2}$ & 1 & 0 & 1.15 & 0.24 & 1.46 & 0.10 \\
$\mathrm{NO}_{\mathrm{x}}$ & 1 & 0 & 1.49 & 0.29 & 5.67 & 0.09 \\
$\mathrm{CO}$ & 1 & 0 & 1.18 & -11.10 & 1.14 & 0.00 \\
$\mathrm{O}$ & 1 & 0 & 1.05 & 2.21 & 1.14 & -1.16 \\
\hline
\end{tabular}

Acknowledgements. The authors thank Head of Botsalano game reserve, M. Khukhela and the game reserve employees for their kind and invaluable help during our measurements. In addition, the authors are grateful to M. Jokinen and E. Sjöberg for their help to organizing the project, and N. Kolu and M. Vuori for their help in drawing the map of Fig. 1. Financial part of the project 
is supported by Academy of Finland, Finnish foreign ministry, Finnish Environment Institute (SYKE) and Yrjö and Vilho Väisälä foundation. The National Center for Atmospheric Research is sponsored by the National Science Foundation.

Edited by: A. Wiedensohler

\section{References}

Aalto, P., Hämeri, K., Becker, E., Weber, R., Salm, J., Mäkelä, J. M., Hoell, C., O’Dowd, C. D., Karlsson, H., Hansson, H.-C., Väkevä, M., Koponen, I. K., Buzorius, G., and Kulmala, M.: Physical characterization of aerosol particles during nucleation events, Tellus, 53B, 344-358, 2001.

Afeti, G. M., Resch, F. J., and Sunnu, A. K.: Size and number distributions of Harmattan dust aerosol in central Ghana, J. Aerosol Sci., 29, 173-174, 1998.

Alastuey, A., Querol, X., Rodríguez, S., Plana, F., Lopez-Soler, A., Ruiz, A., and Mantilla, E: Monitoring of atmospheric particulate matter around sources of secondary inorganic aerosol, Atmos. Environ., 38, 4979-4992, 2004.

Andreae, M. O., Chapuis, A., Cros, B., Fontan, J., Helas, G., Justice, C., Kaufman, Y. J., Minga, A., and Nganga, D.: Ozone and Aitken nuclei over equatorial Africa: Airborne observations during DECAFE88, J. Geophys. Res., 97, 6137-6148, 1992.

Boko, M., Niang, I., Nyong, A., Vogel, C., Githeko, A., Medany, M., Osman-Elasha, B., Tabo, R., and Yanda, P.: Africa. Climate Change 2007: Impacts, Adaptation and Vulnerability, Contribution of Working Group II to the Fourth Assessment Report of the Intergovernmental Panel on Climate Change, edited by: Parry, M. L., Canziani, O. F., Palutikof, J. P., van der Linden, P. J., and Hanson, C. E., Cambridge University Press, Cambridge UK, 433-467, 2007.

Brook, J. R., Dann, T. F., and Burnett, R. T.: The relationship among TSP, $\mathrm{PM}_{10}, \mathrm{PM}_{2.5}$ and inorganic constituents of atmospheric particulate matter at multiple Canadian locations, J. Air Waste Manage. Assoc., 47, 2-19, 1997.

Caminade, C. and Terray, L.: Influence of increased greenhouse gases and sulphate aerosols concentration upon diurnal temperature range over Africa at the end of the 20th century, Geophys. Res. Lett., 33, L15703, doi:10.1029/2006GL026381, 2006.

Carmichael, G., Ferm, M., Thongboonchooa, N., Woo, J., Chan, L. Y., Murano, K., Viet, P., Mossberg, C., Bala, R., Boonjawat, J., Upatum, P., Mohan, M., Adhikary, S., Shrestha, A., Pienaar, J., Brunke, E., Chen, T., Jie, T., Guoan, D., Peng, L., Dhiharto, S., Harjanto, H., Jose, A., Kimani, W., Kirouane, A., Lacaux, J.P., Richard, S., Barturen, O., Cerda, J., Athayde, A., Tavares, T., Cotrina, J., and Bilici, E.: Measurements of sulfur dioxide, ozone and ammonia concentrations in Asia, Africa, and South America using passive samplers, Atmos. Environ., 37, 1293-1308, 2003.

Dal Maso, M., Kulmala, M., Riipinen, I., Wagner, R., Hussein, T., Aalto, P. P., and Lehtinen, K. E. J.: Formation and growth of fresh atmospheric aerosols: eight years of aerosol size distribution data from SMEAR II, Hyytiälä, Finland, Boreal Environ. Res., 10, 323-336, 2005.

Deposition of Biogeochemically Important Trace Species (DEBITS): http://www.igac.noaa.gov/DEBITS.php, 2008.
Duncan, B. N., Logan, J. A., Bey, I., Megretskaia, I. A., Yantosca, R. M., Novelli, P. C., Jones, N. B., and Rinsland, C. P.: Global budget of CO, 1988-1997: Source estimates and validation with a global model, J. Geophys. Res., 112, D22301, doi:10.1029/2007JD008459, 2007.

Eldred, R. A., Cahill, T. A., and Flocchini, R. G.: Composition of $\mathrm{PM}_{2.5}$ and $\mathrm{PM}_{10}$ aerosols in the IMPROVE network, J. Air Waste Manage. Assoc., 47, 194-203, 1997.

Finlayson-Pitts, B. J. and Pitts, J. N.: Chemistry of Upper and Lower Atmosphere, Academic Press, San Diego, 2000.

Gatari, M., Wagner, A., and Boman, J.: Elemental composition of tropospheric aerosols in Hanoi, Vietnam and Nairobi, Kenya, Sci. Total Environ., 341, 241-249, 2005.

Güenther, A., Otter, L., Zimmermann, P., Greenberg, J., Scholes, R., and Scholes, M.: Biogenic hydrocarbon emissions from Southern African savannas, J. Geophys. Res., 101, 25 859-25 865, 1996.

Hameed, A., Joutsensaari, J., Mikkonen, S., Sogacheva, L., Dal Maso, M., Kulmala, M., Cavalli, F., Fuzzi, S., Facchini, M. C., Decesari, S., Mircea, M., Lehtinen, K. E. J., and Laaksonen, A.: Nucleation and growth of new particles in Po Valley, Italy, Atmos. Chem. Phys., 7, 355-376, 2007, http://www.atmos-chem-phys.net/7/355/2007/.

Helmig, D., Oltmans, S. J., Carlson, D., Lamarque, J.-F., Jones, A., Labuschagne, C., Anlauf, K, and Hayden, K.: A review of surface ozone in Polar Regions, Atmos. Environ., 41, 5238-5161, 2007.

Hobbs, P. V.: Clean air slots amid dense atmospheric pollution in Southern Africa, J. Geophys. Res., 108, 8490, doi:10.1029/2002JD002156, 2003.

Holloway, T., Leby II, H., and Kasibhatla, P.: Global distribution of carbon monoxide, J. Geophys. Res., 105, 12 123-12 147, 2000.

Kerminen, V.-M., Lihavainen, H., Komppula, M., Viisanen, Y., Kulmala, M.: Direct observational evidence linking atmospheric aerosol formation and cloud droplet activation, Geophys. Res. Lett., 32, L14803, doi:10.1029/2005GL023130, 2005.

Kgabi, N. A.: Monitoring the levels of atmospheric particulate matter in the North West Province, PhD Thesis, North-West University, 2006

Kulmala, M., Vehkamäki, H., Petäjä, T., Dal Maso, M., Lauri, A., Kerminen, V.-M., Birmili, W., and McMurry, P. H.: Formation and growth rates of ultrafine atmospheric particles: A review of observations, J. Aerosol Sci., 35, 143-176, 2004.

Kurtén, T., Kulmala, M., Dal Maso, M., Suni, T., Reissell, A., Vehkamäki, H., Hari, P., Laaksonen, A., Viisanen, Y., Vesala, T.: Estimation of different forest-related contributions to the radiative balance using observation in southern Finland, Boreal Environ. Res., 8, 275-285, 2003

Laakso, L., Koponen, I. K., Mönkkönen, P., Kulmala, M., Kerminen, V.-M., Wehner, B., Wiedensohler, A., Wu, Z., and Hu, M.: Aerosol particles in the developing world; a comparison between New Delhi in India and Beijing in China, Water Air Soil Poll., 173, 5-20, 2006.

Levy II, H., Klonecki, A. A., and Kasibhatla, P. S.: Simulated tropospheric NOx: Its evaluation, global distribution and individual source contributions, J. Geophys. Res., 104, 25 273-26306, 1999. 
Mirme, A., Tamm, E., Mordas, G., Vana, M., Uin, J., Mirme, S., Bernotas, T., Laakso, L., Hirsikko, A., and Kulmala, M.: A widerange multi-channel Air Ion Spectrometer, Boreal Environ. Res., 12, 247-264, 2007.

Mori, I., Nishikawa, M., Quan, H., and Morita, M.: Estimation of the concentration and chemical composition of Kosa aerosols at their origin, Atmos. Environ., 36, 4569-4575, 2002.

Nyanganyura, D., Maenhaut, W., Mathuthu, M., Makarau, A., Meixner, F.X.: The chemical composition of tropospheric aerosols and their contributing sources to a continental background site in northern Zimbabwe from 1994 to 2000, Atmos. Environ., 41, 2644-2659, 2007.

Oltmans, S. J. and Levy II, H.: Seasonal cycle of surface ozone over the western North Atlantic, Nature, 358, 392-394, 1992.

Otter, L. B., Yang, W., Scholes, M., Meixner, F.: Nitric oxide emissions from a southern African savanna, J. Geophys. Res., 104, 18 471-18 486, 1999.

Otter, L., Güenther, A., Wiedinmyer, C., Fleming, G., Harley, P., Greenberg, J.: Spatial and temporal variations in biegenic volatile organic compound emissions for Africa South of equator, J. Geophys. Res., 108(D13), 8505, doi:10.1029/2002JD002609, 2003.

Piketh, S., van Nierop, M., Rautenbach, C., Walton, N., Ross, K., Holmes, S., Richards, T.: Rustenburg Local Muncipality Air Quality Management Plan, Palace consulting engineers ltd., Republic of South Africa, 2005.

Petäjä, T., Laakso, L., Pohja, T., Siivola, E., Laakso, H., Aalto, P. P., Keronen, P., Kgabi, N. A., and Kulmala, M.: Mobile air quality monitoring trailer for developing countries, Proceedings of International Conference on Nucleation and Atmospheric Aerosols 2007, August 2007, Galway, Ireland, 2007.

Querol, X., Alastuey, A., Puicercus, J. A., Mantilla, E., Miro, J. V., Lopez-Soler, A., Plana, F. and Artinano, B: Seasonal evolution of suspended particles around a large coal-fired power station: particulate levels and sources, Atmos. Environ., 11, 1963-1978, 1998.

Querol, X., Alastuey, A., Ruiz, C. R., Artinano, B., Hansson, H. C., Harrison, R. M., Buringh, E., ten Brink, H. M., Lutz, M., Bruckmann, P., Straehl, P., and Schneider, J.: Speciation and origin of PM10 and PM2.5 in selected European cities, Atmos. Environ., 38, 6547-6555, 2004.

Rodrigues, S. and Guerra, J.-C.: Monitoring of ozone in a marine environment in Tenerife (Canary Islands), Atmos. Environ., 135, 1829-1841, 2001.

Rodriguez, S., Querol, X., Alastuey, A., and De L Rosa, J.: Atmospheric particulate matter and air quality in the Mediterranean: a review, Environ. Chem. Lett., 5, 1-7, 2007.
Ross, K. E., Piketh, S. J., Bruintjes, R. T., Burger, R. P., Swap, R. J., and Annegarn, H. J.: Spatial and seasonal variations in CCN distribution and the aerosol-CCN relationship over southern Africa, J. Geophys. Res., 108, 8481, doi:10.1029/2002JD002384, 2003.

Scheel, H. E., Areskoug, H., Geiss, H., Gomiscek, B., Granby, K., Haszpra, L., Klasinc, L., Kley, D., Laurila, T., Lindskog, A., Roemer, M., Schmitt, R., Simmonds, P., Solberg, S., and Tounape, G.: On the spatial distribution and seasonal variation of lower-tropospheric ozone over Europe, J. Atmos. Chem., 28, 11-28, 1997.

Sinha, P., Hobbs, P. V., Yokelson, R. J., Blake, D. R., Gao, S., and Kirchstetter, T. W.: Distributions of trace gases and aerosols during dry biomass burning season in Southern Africa, J. Geophys. Res., 108(D17), 4536, doi:10.1029/2003JD003691, 2003.

Solomon, P., Cowling, E., Hidy, E., and Furiness, C.: Comparison of scientific findings from major ozone field studies in North America and Europe, Atmos. Environ., 34, 1885-1920, 2000.

South African Weather Service: Climatologic statistics for Mafikeng, http://www.weathersa.co.za/Climat/Climstats/ MmabathoStats.jsp, 2007.

Swap, R. J., Annegarn, H. J., Suttles, J. T., King, M. D., Platnick, S., Privette, J. L., and Scholes, R. J.: Africa burning: A thematic analysis of the Southern African Regional Science Initiative (SAFARI 2000), J. Geophys. Res., 108(D13), 8465, doi:10.1029/2003JD003747, 2003.

Tammet, H.: Size and mobility of nanometer particles, clusters and ions, J. Aerosol Sci., 26, 459-475, 1995.

Tammet, H.: Reduction of air ion mobility to standard conditions, J. Geophys. Res., 103, 13 933-13 937, 1998.

Tyson, P. D., Garstang, M., and Swap, R.: Large-scale recirculation of Air over Southern Africa, J. Appl. Meteorol., 35, 2218-2236, 1996.

Van Dingenen, R., Raes, F., Putaud, J.-P., Baltensperger, U., Charron, A., Facchini, M. C., Decesari, S., Fuzzi, S., Gehrig, R., Hansson, H.-C., Harrison, R.-M., Huglin, C., Jones, A., Laj, P., Lorbeer, G., Maenhaut, W., Palmgren, F., Querol, X., Rodriguez, S., Schneider, J., ten Brink, H., Tunved, P., Törseth, K., Wehner, B., Weingartner, E., Wiedensohler, A., and Wahlin, P.: A European aerosol phenomenology: physical characteristics of particulate matter at kerbside, urban, rural and background sites in Europe, Atmos. Environ., 38, 2561-2577, 2004.

Went, F. W.: Blue hazes in the atmosphere, Nature, 187, 641-643, 1960.

Winklmayr, W., Reischl, G., Lindner, A., and Berner, A.: A new electromobility spectrometer for the measurement of aerosol size distributions in the size range from 1 to $1000 \mathrm{~nm}$, J. Aerosol Sci., 22, 289-296, 1991. 